\title{
Persistent Nav1.6 current at axon initial segments tunes spike timing of cerebellar granule cells
}

\author{
Nancy Osorio ${ }^{1}$, Laurence Cathala ${ }^{2}$, Miriam H. Meisler $^{4}$, Marcel Crest ${ }^{1}$, Jacopo Magistretti ${ }^{3}$ \\ and Patrick Delmas ${ }^{1}$ \\ ${ }^{1}$ Centre de Recherche en Neurobiologie et Neurophysiologie de Marseille, UMR 6231, CNRS, Université de la Méditerranée, CS80011, Bd Pierre Dramard, \\ 13344 Marseille Cedex 15, France \\ ${ }^{2}$ Physiologie cérébrale, Université Paris Descartes, CNRS UMR 8118, 45 Rue des Saints Pères, 75006 Paris, France \\ ${ }^{3}$ Dipartimento di Fisiologia, Università degli Studi di Pavia, Via Forlanini 6, 27100 Pavia, Italy \\ ${ }^{4}$ Department of Human Genetics, 4909 Buhl, University of Michigan, Ann Arbor, MI 48109-0618, USA
}

Cerebellar granule (CG) cells generate high-frequency action potentials that have been proposed to depend on the unique properties of their voltage-gated ion channels. To address the in vivo function of Nav1.6 channels in developing and mature CG cells, we combined the study of the developmental expression of Nav subunits with recording of acute cerebellar slices from young and adult granule-specific $S c n 8 a$ KO mice. Nav1.2 accumulated rapidly at early-formed axon initial segments (AISs). In contrast, Nav1.6 was absent at early postnatal stages but accumulated at AISs of CG cells from P21 to P40. By P40-P65, both Nav1.6 and Nav1.2 co-localized at CG cell AISs. By comparing $\mathrm{Na}^{+}$currents in mature CG cells (P66-P74) from wild-type and CG-specific $S c n 8 a \mathrm{KO}$ mice, we found that transient and resurgent $\mathrm{Na}^{+}$currents were not modified in the absence of Nav1.6 whereas persistent $\mathrm{Na}^{+}$current was strongly reduced. Action potentials in conditional Scn8a KO CG cells showed no alteration in threshold and overshoot, but had a faster repolarization phase and larger post-spike hyperpolarization. In addition, although Scn8a KO CG cells kept their ability to fire action potentials at very high frequency, they displayed increased interspike-interval variability and firing irregularity in response to sustained depolarization. We conclude that Nav1.6 channels at axon initial segments contribute to persistent $\mathrm{Na}^{+}$current and ensure a high degree of temporal precision in repetitive firing of CG cells.

\begin{abstract}
(Received 29 October 2009; accepted after revision 18 December 2009; first published online 21 December 2009)
Corresponding author P. Delmas: Centre de Recherche en Neurobiologie et Neurophysiologie de Marseille, UMR 6231, CNRS, Université de la Méditerranée, CS80011, Bd Pierre Dramard, 13344 Marseille Cedex 15, France. Email: patrick.delmas@univmed.fr
\end{abstract}

\begin{abstract}
Abbreviations AHP, afterhyperpolarization; AIS, axon initial segment; AP, action potential; BSA, bovine serum albumin; CG, cerebellar granule; DIV, days in vitro; P, post-natal days; ISI, inter-spike interval; KO, knock-out; RT, room temperature.
\end{abstract}

\section{Introduction}

Ten voltage-gated sodium (Nav) channel $\alpha$ subunits (Nav1.1-1.9, Nax) have been identified to date (Goldin, 2001). Each isoform has its own regional, cellular and developmental expression (Trimmer \& Rhodes, 2004) but the reasons for this diversity are still largely unknown.

The Nav1.6 channel is highly expressed in the adult cerebellum, where it serves a specialized role in regulating the activity patterns of cerebellar neurons. In Purkinje cells lacking Nav1.6 channels both spontaneous firing activity and high-frequency discharge are impaired (Raman et al. 1997; Khaliq et al. 2003). Nav1.6 channels are particularly important because they are localized at the axon initial segments (AISs), where action potentials (APs) are initiated (Waxman \& Quick, 1978; Kaplan et al. 2001; Boiko et al. 2001, 2003; Osorio et al. 2005; Lorincz \& Nusser, 2008; Royeck et al. 2008; Hu et al. 2009). Consistently, mice with disrupted Nav1.6 expression exhibited neurological syndromes including ataxia, dystonia and juvenile lethality (Meisler et al. 2004; Meisler \& Kearney, 2005), and cognition is impaired in human heterozygotes for a null allele of Nav1.6 (Trudeau et al. 2006), suggesting that Nav1.6 is crucial for impulse propagation at postnatal stages and later in life. 
Collectively, these data indicate that Nav1.6 plays a critical role in faithfully transmitting high frequency firing, which could reflect the distinctive biophysical nature of Nav1.6 compared to other Nav isoforms. Particularly, Nav1.6 channels have been widely associated with the presence of resurgent $\mathrm{Na}^{+}$currents, thereby providing a depolarizing drive following firing of single APs (Raman \& Bean, 1997; Swensen \& Bean, 2003). Another property that distinguishes Nav1.6 channels is their propensity to generate larger steady-state $\mathrm{Na}^{+}$currents (Smith et al. 1998; Rush et al. 2005). These 'persistent' $\mathrm{Na}^{+}$currents critically influence AP firing at just-threshold levels of stimulation (Crill, 1996) and are greatly reduced in Purkinje and cortical neurons from Nav1.6-null mice (Raman et al. 1997; Maurice et al. 2001).

Our previous study of rat cerebellar granule (CG) cells has shown that Nav1.2 precedes Nav1.6 at developing AISs in culture (Osorio et al. 2005). The functional benefit of this differential developmental pattern is still unclear, but it might be necessary for the appearance of the complex firing pattern of mature CG cells (D'Angelo et al. 2001; Isope \& Barbour, 2002; Chadderton et al. 2004; Isope et al. 2004; Jörntell \& Ekerot, 2006). Inactivation of Nav1.6 specifically in cerebellar granule cells resulted in impaired rotarod performance and reduction of evoked firing in Purkinje cells (Levin et al. 2006). However, it is not clear how Nav1.6 subunits contribute to the biophysically distinct $\mathrm{Na}^{+}$currents of CG cells (Osorio et al. 2005; Magistretti et al. 2006) and set their intrinsic firing properties in vivo.

To test the selective contribution of Nav1.6 channels to CG cell firing properties, we studied the developmental expression pattern of Nav1.2 and Nav1.6 in situ. We found that developmental targeting of Nav1.6 subunits at AISs is complete only into adulthood, making the use of Nav1.6-null mice inappropriate, as they die prematurely. We therefore generated $S c n 8 a^{\text {flox/flox }}-\mathrm{Cre}^{+}$transgenic mice showing selective inactivation of Nav1.6 in CG cells. We show that Nav1.6 channels at AISs contribute to persistent but not resurgent $\mathrm{Na}^{+}$currents, and regulate the firing regularity of granule neurons in adult cerebellum.

\section{Methods}

\section{Ethical approval}

Animal use followed the guidelines established by the European animal care and use committee (N. 86/609/ CEE) and complied with The Journal's policies and regulations (Drummond, 2009). Mice older than P14 were anaesthetized with halothane or isoflurane and killed by decapitation. The total number of mice used in this study was 55.

\section{Scn8a null mice, conditional Scn8a KO mice and genotyping}

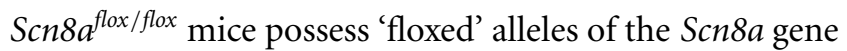
containing loxP sites flanking the first coding exon (Levin \& Meisler, 2004). Scn8 $a^{\text {flox/flox }}$ mice were crossed with $\mathrm{BAC} \alpha 6$-Cre transgenic mice, in which Cre expression is under the control of the granule-specific $\mathrm{GABA}_{\mathrm{A}}$ receptor $\alpha 6$ subunit promoter (Laurie et al. 1992; Aller et al. 2003). The loxP exon is deleted by exposure to Cre recombinase (Cre), resulting in a complete loss of expression of Nav1.6. In that manner, disrupted Nav1.6 expression is restricted

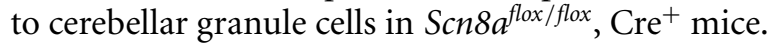

Genotyping used DNA extracted from mouse tails (Truett et al. 2000). Mouse tails were incubated for $20 \mathrm{~min}$ at $95^{\circ} \mathrm{C}$ in a dissociation solution consisting of $25 \mathrm{~mm} \mathrm{NaOH}$ and $0.2 \mathrm{~mm}$ EDTA; the reaction was then stopped with $40 \mathrm{~mm}$ Tris- $\mathrm{HCl}$. The resulting solution was centrifugated $5 \mathrm{~min}$ at $2000 \mathrm{~g}$ and used for PCR reactions. PCR amplification of wild-type (WT) and floxed alleles of Scn $8 a$ used the F2 (5'-GTG TGT GAT TCT CAA CAG TGG GTT- $3^{\prime}$ ) and R2 (5'-GTC TGT AAG AAG GCC TGA AAG TGA-3') primers (Levin \& Meisler, 2004). Cre transgenes were genotyped with the Cre-specific forward primer 5'-ACT TAG CCT GGG GGT AAC TAA ACT-3' and the reverse primer $5^{\prime}$-GGT ATC TCT GAC CAG AGT CAT CCT- $3^{\prime}$. The reaction consisted of $30 \mathrm{~s}$ at $94^{\circ} \mathrm{C}, 30 \mathrm{~s}$ at $55^{\circ} \mathrm{C}$ and $1 \mathrm{~min}$ at $72^{\circ} \mathrm{C}$ (35 cycles) and $5 \mathrm{~min}$ at $72^{\circ} \mathrm{C}$. PCR products were separated on a $2 \%$ agarose gel allowing resolution of a $800 \mathrm{bp}$ product for the WT Scn8a allele, a 900 bp product for the floxed Scn $8 a$ allele and a 300 bp product for the Cre transgene. Mice homozygous for the floxed allele of Scn8a produce normal levels of Nav1.6 protein in the absence of Cre (Levin \& Meisler, 2004). In addition, $\mathrm{Na}^{+}$current properties in C57BL/6, Scn8a $a^{f l o x}$ and Scn8a flox/flox mice were indistinguishable and the data were pooled as WT mice.

The med Scn8a-null mutation arose from insertion of a transposable L1 element into exon 2, causing aberrant splicing and disruption in the open reading frame (Kohrman et al. 1996). This mutation was maintained by crossing to strain $\mathrm{C} 3 \mathrm{Heb} / \mathrm{FeJ}$. Homozygous med mice developed severe muscle atrophy, weakness and progressive paralysis of the hindlimbs and died by 3 weeks of age. Throughout the manuscript, the term 'med' refers to the animals that were homozygous for the recessive null mutation (Burgess et al. 1995; Kohrman et al. 1996).

\section{Reverse transcriptase-PCR}

Total RNA was extracted from cerebella and

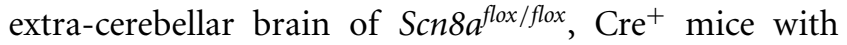
Tri-Reagent (Sigma, Saint-Louis, MO, USA) according to the manufacturer's recommendation. Reverse 
transcription reactions with oligo $(\mathrm{dT})_{20}$ primers were performed with the cloned AMV reverse transcriptase following the manufacturer's protocol (Invitrogen, Grand Island, NY, USA), using $3 \mu \mathrm{g}$ of total RNA. PCR on reverse-transcribed cDNA were performed with a forward primer located in the $5^{\prime}$-UTR (5'-CAC TGA GGT TTG GAC AGG TTG TCA CC- $3^{\prime}$ ) and a reverse primer located in the exon 3 (5'-ATA CAC AGT TGG TCA GGA TGG TGC-3') (Drews et al. 2005). PCR products were separated on a $2 \%$ agarose gel allowing resolution of a 650 bp product for the floxed Scn8a mRNA and a $350 \mathrm{bp}$ product for the truncated $S c n 8 a$ mRNA.

\section{Antibodies}

Primary antibodies used and dilutions were as follows: serine-rich domain of ankyrin-G node (polyclonal, Bouzidi et al. 2002), 1/500; ankyrin-G (monoclonal 4G3F8, Santa Cruz Biotechnology, Santa Cruz, CA, USA), 1/50; Nav1.1 (polyclonal AB5204, Chemicon), 1/150; Nav1.2 polyclonal (ASC-002, Alomone Laboratories, Jerusalem, Israel), 1/100; Nav1.2 monoclonal (K69/3, Upstate Biotechnology, Lake Placid, NY, USA), 1/100; Nav1.6 polyclonal (ASC-009, Alomone), 1/100; Nav1.6 monoclonal (K87A/10, Neuromab, Davis, CA, USA), 1/200. Alexa Fluor488- and Alexa Fluor546-conjugated goat secondary antibodies were used to detect rabbit polyclonal antibodies, and Alexa Fluor555-conjugated goat secondary antibodies were used for visualization of the mouse monoclonal antibodies (all from Molecular Probes, Eugene, OR, USA).

The specificity of the Nav1.6 antibodies was tested on cryosections of cerebella of med mice. Because med mice die before 3 weeks of age, we performed control immunostaining on P19 med mice cryosections. In addition, because WT CG cells did not express Nav1.6 at AISs before P20 (see Figs 1 and 2), comparison were made between WT and med Purkinje cell AISs, which have been shown to cluster Nav1.6 at this developmental stage (Jenkins \& Bennett, 2001). Dual labelling with polyclonal anti-ankyrin $\mathrm{G}$ antibody (to mark AISs) and monoclonal Nav1.6 antibody or monoclonal anti-ankyrin $\mathrm{G}$ antibody and polyclonal anti-Nav1.6 antibody did not reveal staining of med Purkinje cell AISs (not shown), demonstrating that the Nav1.6 antibodies were specific.

\section{Tissue preparation and immunostaining of cryosections}

Mice older than P14 were anaesthetized with halothane and killed by decapitation. Cerebella were rapidly dissected out and frozen in OCT embedding matrix (Cellpath, Hemel Hempstead, UK) bathed in chilled isopentane. Tissues were sagitally cryosectioned at $14-18 \mu \mathrm{m}$, transferred to SuperFrostPlus slides (Fisher Scientific, Houston, TX, USA) and stored at $-80^{\circ} \mathrm{C}$ until processed. Slides with cryosections were thawed at room temperature (RT), washed in phosphate-buffered saline (PBS) and then incubated for $40 \mathrm{~min}$ at RT in blocking solution containing $3 \%$ BSA and $0.1 \%$ Triton X-100. Primary antibodies were diluted in blocking solution and applied to sections to be incubated overnight at $4^{\circ} \mathrm{C}$ in sealed humidified chambers. Slices were then washed three times for $15 \mathrm{~min}$ in PBS. Secondary antibodies were applied in 3\% BSA-containing PBS for 40 min at RT in the dark. After six washes in PBS, sections were mounted in PBS-50\% glycerol.

\section{Confocal imaging and deconvolution}

Images were acquired using a TCS SP2 laser-scanning confocal microscope (Leica Microsystems, Mannheim, Germany), initially processed using Leica Confocal Software (LCS Lite) and later exported into Adobe Photoshop for final processing. Images comparing WT and med cerebellar granule cells or WT and granule-specific KO mice cerebella were acquired and digitally processed with identical parameters. No staining was detected in sections or cultures incubated with the secondary antibodies alone.

In order to compare the fluorescence intensities of Nav (Nav1.2 and Nav1.6) and ankyrin G antibodies at AISs over age, images of double labelled sections were acquired using a set of acquisition parameters that was specific for each antibody. LCS Lite software was used to measure intensities of fluorescence on planar projections of confocal raw images spanning $1.6 \mu \mathrm{m}$. For each pair of ankyrin G-specific and isotype-specific images of the same field, regions of interest encompassing a single AIS $(\sim 0.4 \mu \mathrm{m})$ were defined in the ankyrin $\mathrm{G}$ image and the intensities of both ankyrin G- and isotype-specific fluorescences were measured. The measurements were repeated in an adjacent unlabelled area and the resulting background intensities were subtracted from the AIS fluorescence signal. The intensity ratios of Nav1.2 or Nav1.6 signal over ankyrin-G intensity at individual AISs were plotted against age (Fig. 2). Ankyrin G staining intensity was used as reference because it remains stable over age (Fig. 2B).

Images acquired for the deconvolution process were taken with an oil immersion objective $63 \times \mathrm{NA}$ and pixel sizes were adjusted to $58 \mathrm{~nm} \times 58 \mathrm{~nm}$ with a z-sectioning interval of $163 \mathrm{~nm}$. Raw images were transferred to a Silicon Graphics Octane workstation, visualized with Imaris software and deconvolved by the Huygens Professional software (Scientific Volume Imaging, Hilversum, The Netherlands). We determined the microscope's point-spread function from images of spherical beads acquired with the same parameters as raw 
images of cerebellum and used the Classical Maximum Likehood Estimation as restoration image process.

As indicated in the figures, images show either planar projections of a series of successive confocal images or representative individual confocal sections.

\section{Voltage-clamp experiments: slice preparation and recording}

To prepare cerebellar slices for voltage-clamp, patch-clamp experiments, mice (P66-P74) were anaesthetized by inhalation of isoflurane (Merial, Toulouse, France) and decapitated. The procedures followed for extracting the cerebellum, cutting sagittal sections of the cerebellar vermis ( $220 \mu \mathrm{m}$ thick), and maintaining the slices before recording were exactly the same as described elsewhere (Magistretti et al. 2006). The apparatus employed and the procedures followed for patch-clamp recordings in the voltage-clamp mode are also described elsewhere (Castelli et al. 2007a). Briefly, the recording chamber was mounted on the stage of an upright microscope (Axioskop 2 FS; Zeiss, Oberkochen, Germany) equipped with differential-contrast optics and a near-infrared charge-coupled device (CCD) camera used to improve cell visualization during the approaching and patching procedures. Slices were perfused with a solution suitable for isolating $\mathrm{Na}^{+}$currents, containing (in mM): 100 $\mathrm{NaCl}, 26 \mathrm{NaHCO}_{3}, 19.5$ tetraethylammonium chloride (TEA-Cl), $3 \mathrm{KCl}, 2 \mathrm{MgCl}_{2}, 2 \mathrm{CaCl}_{2}, 2 \mathrm{BaCl}_{2}, 0.5 \mathrm{CdCl}_{2}$, 4 4-aminopyridine (4-AP), 11 D-glucose ( $\mathrm{pH} 7.4$ by saturation with $95 \% \mathrm{O}_{2}-5 \% \mathrm{CO}_{2}$ ). Patch pipettes were fabricated from thick-wall borosilicate glass capillaries (CEI GC 150-7.5; Harvard Apparatus, Edenbridge, UK) and were filled with an intracellular solution containing (in mM): 104 CsF, 50 TEA-Cl, $2 \mathrm{MgCl}_{2}, 10$ Hepes, 10 EGTA, 2 $\mathrm{Na}-\mathrm{ATP}$, and $0.2 \mathrm{Na}-\mathrm{GTP}$ (pH adjusted to 7.2 with $\mathrm{CsOH}$ ). The patch pipettes had a resistance of 5-8 $\mathrm{M} \Omega$ when filled with the above solution. Liquid junction potential $\left(V_{\mathrm{j}}\right)$, estimated as explained in Castelli et al. (2007a), was $5.5 \mathrm{mV}$. The voltage values specified in the text and figures are uncorrected values (actual membrane potential values can be calculated from nominal command potentials, $V_{\text {com }}$, as: $\left.V_{\mathrm{m}}=V_{\text {com }}-V_{\mathrm{j}}\right)$.

Tight seals $(>5 \mathrm{G} \Omega)$ and the whole-cell configuration were obtained by suction according to the standard technique (Hamill et al. 1981). Voltage-clamp recordings of $\mathrm{Na}^{+}$currents were performed at room temperature $\left(21-22^{\circ} \mathrm{C}\right)$ by means of an Axopatch $200 \mathrm{~B}$ patch-clamp amplifier (Axon Instruments/Molecular Devices, Union City, CA, USA). Series resistance $\left(R_{\mathrm{s}}\right)$, which was evaluated on-line and continually monitored during the recording (see Castelli et al. 2007a), averaged 22.1 $\pm 4.6 \mathrm{M} \Omega$ ( $n=34$ ), and was always compensated by $\sim 95 \%$. The program Clampex of the pCLAMP 8.2 software package
(Axon Instruments) was used for commanding voltage protocols and digitally acquiring current signals. In all recordings the nominal holding potential was $-80 \mathrm{mV}$. Current signals were low-pass filtered at $5 \mathrm{kHz}$ and digitized at $50 \mathrm{kHz}$ (step protocols) or $10 \mathrm{kHz}$ (ramp protocols). On-line subtraction of leak and capacitive currents was performed using a $P / 4$ routine when step protocols were applied. No on-line subtraction procedure was adopted for ramp protocols. Tetrodotoxin (TTX; Alomone Laboratories) was always applied in the bath with the superfusing solution at the end of the experiment, so as to obtain residual TTX-insensitive currents to be subtracted from control traces and isolate voltagedependent $\mathrm{Na}^{+}$currents.

\section{Current-clamp experiments: slice preparation and recording}

Parasagittal slices $(200 \mu \mathrm{m})$ were cut from the cerebellar vermis of mice aged between P40 and P65, as described in Cathala et al. (2003). Briefly, mice were decapitated and the cerebellum was rapidly removed and placed in cold 'slicing' $\left(2-4^{\circ} \mathrm{C}\right)$ solution of the following composition (mM): $125 \mathrm{NaCl}, 2.5 \mathrm{KCl}, 2 \mathrm{CaCl}_{2}, 1 \mathrm{MgCl}_{2}, 26 \mathrm{NaHCO}_{3}$, $1.25 \mathrm{NaH}_{2} \mathrm{PO}_{4}, 25$ glucose, 0.5 ascorbic acid and 1 kynurenic acid, pH 7.3 when bubbled with $95 \% \mathrm{O}_{2}-5 \%$ $\mathrm{CO}_{2}$. Slices were cut from the dissected cerebellum using a Leica VT1000S (Leica Microsystems, Wetzlar, Germany) or a Vibroslicer (Campden Instrument Ltd) vibrating microtome; these were incubated in slicing solution at $30^{\circ} \mathrm{C}$ for $45 \mathrm{~min}$ and subsequently were maintained without kynurenic acid at room temperature for up to $7 \mathrm{~h}$. Patch-clamp recordings were made at room temperature with an EPC9 amplifier (HEKA Elektronik, Lambrecht/Pfalz, Germany), low-pass filtered at $5 \mathrm{kHz}$ and digitized at $20 \mathrm{kHz}$. Patch pipettes had a resistance of 8-11 Mwhen filled with the internal solution consisting of (in mM): $110 \mathrm{~K}^{-\mathrm{MeSO}_{4}}$, 40 Hepes, 0.15 BAPTA, 6 $\mathrm{NaOH}, 0.02 \mathrm{CaCl}_{2}, 4.6 \mathrm{MgCl}_{2}, 4 \mathrm{Na}$-ATP and $0.3 \mathrm{Na}$-GTP (adjusted to $\mathrm{pH} 7.3$ with $\mathrm{KOH}$ ). Capacitance measures were determined directly from the amplifier setting. All voltage recordings were corrected for a measured liquid junction potential of $6 \mathrm{mV}$.

\section{Data analysis}

Data were analysed using pCLAMP 8.2 (Axon Instruments) software. $\mathrm{Na}^{+}$currents were re-filtered off-line at $3 \mathrm{kHz}$. Current amplitude was measured at the peak of each tracing. $I_{\mathrm{NaR}}$ kinetics was studied by fitting the current activation and decay phases with a double exponential function in the form: $I=A_{1} \exp \left(-t / \tau_{1}\right)+A_{2} \exp \left(-t / \tau_{2}\right)+C . \mathrm{Na}^{+}$ permeabilities $\left(P_{\mathrm{Na}}\right)$ were calculated from current 
amplitudes $\left(I_{\mathrm{Na}}\right)$ by applying the Goldman equation in the form:

$$
\begin{aligned}
P_{\mathrm{Na}}= & I_{\mathrm{Na}}\left(R T / F^{2} V_{\mathrm{m}}\right)\left[1-\exp \left(-F V_{\mathrm{m}} / R T\right)\right] \\
& /\left\{\left[\mathrm{Na}^{+}\right]_{\mathrm{i}}-\left[\mathrm{Na}^{+}\right]_{\mathrm{o}} \exp \left(-F V_{\mathrm{m}} / R T\right)\right\},
\end{aligned}
$$

in which the nominal intra- and extracellular $\mathrm{Na}^{+}$ concentration values ( 4.2 and $126 \mathrm{mM}$, respectively) were introduced. Fittings with the Boltzmann function, $\left.P_{\mathrm{Na}}=A /\left\{1+\exp \left[\left(V-V_{1 / 2}\right) / k\right)\right]\right\}$ were carried out using Origin 6.0 (OriginLab Corp., Northampton, MA, USA).

Current-clamp data obtained on cerebellar slices were analysed in the Igor Pro 5.01 environment (Wavemetrics Inc, Lake Oswego, OR, USA) using Neuromatic software (Jason Rothman, University College London, UK; http://www.neuromatic.thinkrandom.com). Measures of $\mathrm{AP}$ overshoot, rise time, half-width and AHP amplitude were performed on the first action potential elicited by liminar current injection, unless otherwise stated.

Results are presented as means \pm S.E.M., unless otherwise specified (Fig. 4), and $n$ represents the number of cells examined. When data were normally distributed (Shapiro-Wilk test), statistical difference between groups were tested using Student's two-tailed $t$ test for unpaired data (unless otherwise stated). $P$ was considered significant at $P<0.05 .{ }^{*},{ }^{* *}$ and ${ }^{* * *}$ indicate $P<0.05, P<0.01$ and $P<0.001$, respectively.

\section{Results}

\section{Nav1.2 and Nav1.6 accumulate differentially at developing axon initial segments of CG cells in situ}

We have shown previously that in rat cultured CG cells, Nav1.2 channels are clustered in early-formed AISs (days in vitro (DIV) 7 on), and that during maturation Nav1.6 becomes the predominant Nav channel isoform at these sites (Osorio et al. 2005).

Therefore, we asked whether a similar developmental progression of Nav1.6 expression also occurs in mice CG cell AISs in situ. We examined Nav subunit expression in cryosections of mice cerebella early in postnatal development, starting at P10. By then most CG cells have attained the internal granular layer and show ankyrin G-defined AISs (Supplemental Fig. 1A). Faint Nav1.2 immunoreactivity was observed in $\sim 80 \%$ of these ankyrin G-positive CG cell AISs (Supplemental Fig. 1A; see Fig. $2 A$ for average data). Deconvolved confocal sections, shown in the bottom panel of Supplemental Fig. $1 A$, revealed that Nav1.2 staining extended through the entire length of the CG cell AISs. In marked contrast, no Nav1.6 immunoreactivity was observed in ankyrin G-positive AISs in the granular layer, whereas Nav1.6 and ankyrin G were co-expressed at Purkinje cell AISs (Supplemental Fig. 1B). At P14, Nav1.6 immunostaining remained undetectable in the granular layer. Nav1.2 was still present and appeared to accumulate at AISs during this period, as evidenced by the increase in the Nav1.2 versus ankyrin $G$ intensity ratio. Nav1.2 expression remained high in most AISs up to P30 (Figs $1 A$ and $2 A$ and $B$ ).

The first instances of dim Nav1.6 fluorescence were seen at $\mathrm{P} 21$ in about $30 \%$ of CG cell AISs (Figs $1 A$ and $2 A$ ). From P21 through adulthood, the number of Nav1.6 positive AISs increased sharply, along with an increase in Nav1.6 labelling intensity (Fig. 2A and B). By P60, 90\% of ankyrin G-positive AISs in the granular layer were positive for Nav1.6 and Nav1.2 (Figs $1 A$ and $2 A$ ). At this stage, Nav1.6 staining appeared regular and extended nearly through the entire ankyrin G-positive AISs (bottom panel in Fig. $1 B$ ), while Nav1.2 labelling intensity, although present, was reduced (bottom panel in Figs $1 A$ and $2 B$ ). Thus, Nav1.2 channels cluster first at early CG cell AISs, whereas Nav1.6 appears with maturation. It should be noted that neither Nav1.2 nor Nav1.6 (or PanNav immunoreactivities, not shown) was seen in the cell bodies and dendrites of mature CG cells, consistent with the observation that $\mathrm{Na}^{+}$channel activity was absent from the granule cell somato-dendritic compartment in cerebellar slices (Diwakar et al. 2009).

\section{Maturation of AISs and developmental accumulation of Nav1.2 at AISs are unchanged in CG cells from granule-specific Scn8a KO mice}

To investigate Nav1.6 function in CG cells, we used gene targeting to generate granule-specific $\mathrm{KO}$ mice deficient in the Nav1.6 subunit. Homozygous mice for the floxed allele of $\operatorname{Scn} 8 a$ ( $S c n 8 a^{\text {flox/flox }}$ mice) were crossed with BAC $\alpha 6$-Cre transgenic mice, in which expression of the Cre recombinase (Cre) is under the control of the granule-specific $\mathrm{GABA}_{\mathrm{A}}$ receptor $\alpha 6$ subunit promoter (Aller et al. 2003; Levin \& Meisler, 2004; Levin et al. 2006). Deletion of the loxP exon by exposure to Cre in $\operatorname{Scn} 8 a^{f l o x} / f l o x-\mathrm{Cre}^{+}$recombinant mice resulted in the inactivation of the Scn8a gene only in CG cells. Mice homozygous for the deleted Scn8a allele were viable, had normally developing cerebella and had no visible motor impairment, but a slower rate of improvement was observed in 5-month-old mice with the rotarod test (Levin et al. 2006). We refer hereafter to these mice as Scn8a CG $\mathrm{KO}$ mice.

Based on the onset of Cre expression in the $\mathrm{Cre}^{+}$line (Aller et al. 2003), Scn8a inactivation may be expected to occur gradually after P7. Deletion of Scn8a exon 1 genomic DNA was detected in cerebella from P30 Scn8a CG KO mice (Fig. 3A). Scn $8 a$ mRNA lacking exon 1 was also detected by RT-PCR in cerebella but not in extra-cerebellar regions of $S c n 8 a$ CG KO mice (Fig. 3A).

To verify that homologous deletion of the Scnsa allele was associated with a concomitant reduction in 
$A$
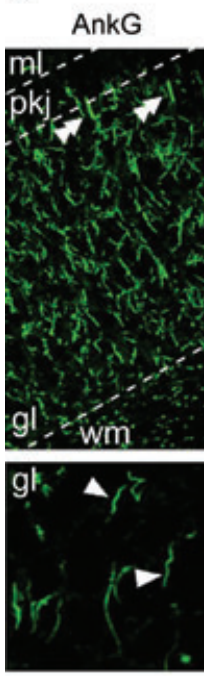

$B$
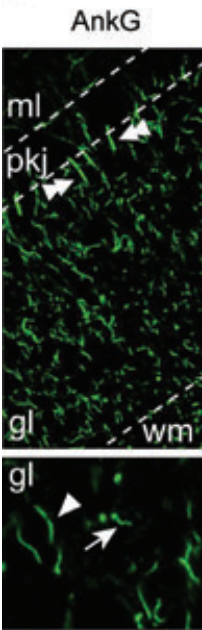

gl

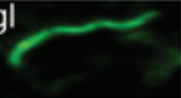

Postnatal day 21

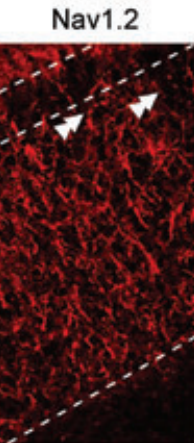

merge
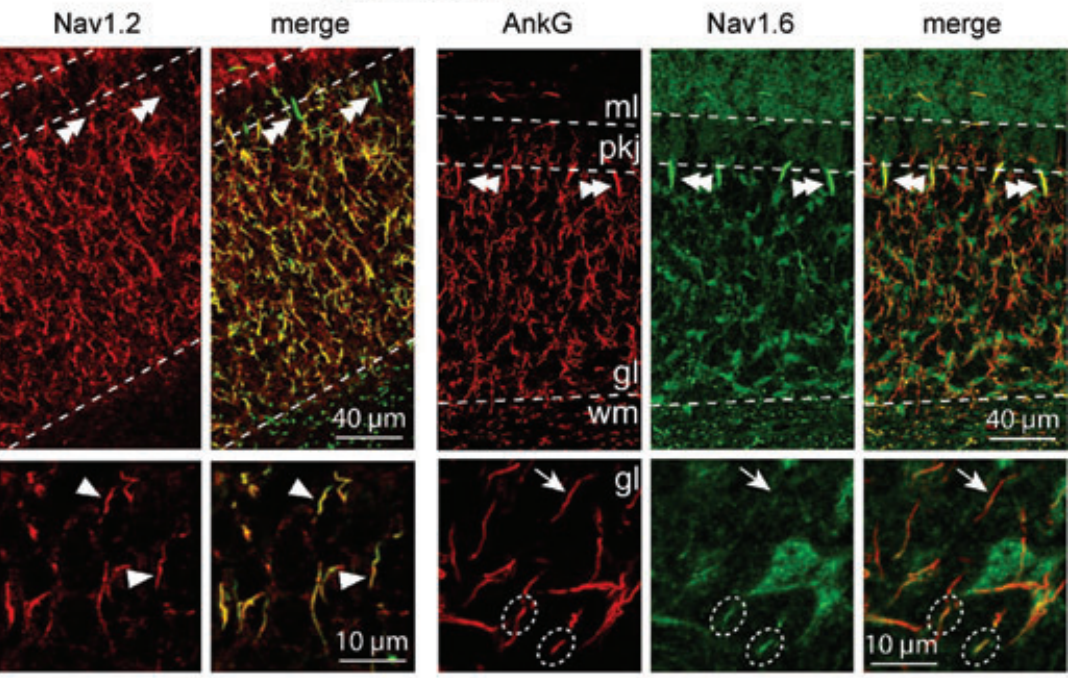

Postnatal day 60
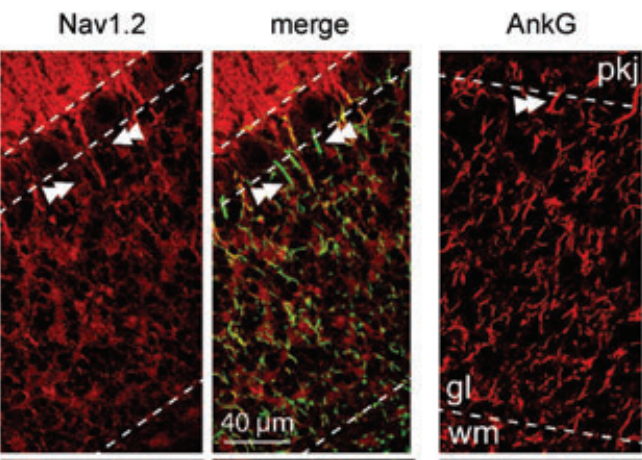

Nav1.6

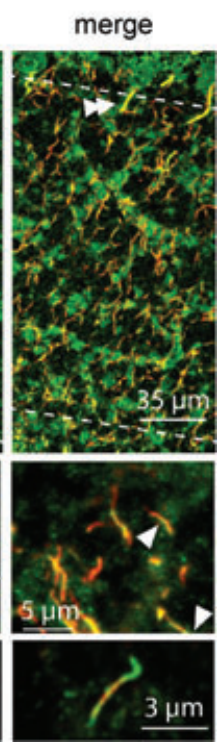

Figure 1. Differential expression of Nav1.6 and Nav1.2 at developing CG cell AISs

A, cryosections of a P21 WT mouse cerebellum were double-labelled with anti-ankyrin G (polyclonal) and anti-Nav1.2 (monoclonal K69/3) antibodies (left panels) or with anti-ankyrin G (monoclonal, 4G3F8) and anti-Nav1.6 (polyclonal ASC-009) antibodies (right panels). Upper panels, virtually all AlSs located in the granular layer were stained with the anti-Nav1.2 antibody, whereas Purkinje cell AlSs (double arrowheads) and nodes located in the white matter were clearly devoided of Nav1.2 labelling. Purkinje cell AISs as well as nodes in the white matter exhibited Nav1.6 staining. Images are projections of 21 consecutive optical sections spanning $3.3 \mu \mathrm{m}$. Bottom panels, expanded deconvolved projections of 11 consecutive optical sections spanning $1.7 \mu \mathrm{m}$ in the granular layer, in which most CG cell AlSs expressed Nav1.2 (arrowheads) and did not express Nav1.6 (arrows) or showed the first signs of Nav1.6 clustering at AlSs (dashed circles). B, cryosections of a P60 WT mouse cerebellum were double-labelled with anti-ankyrin G (polyclonal) and anti-Nav1.2 (monoclonal K69/3) antibodies (left panels) and with anti-ankyrin G (monoclonal, 4G3F8) and anti-Nav1.6 (polyclonal ASC-009) antibodies (right panels). Upper panels, most AISs located in the granular layer were stained with the anti-Nav1.2 antibody, whereas Purkinje cell AISs (double arrowheads) and nodes located in the white matter were negative. Purkinje cell AISs and CG cell AlSs (arrowheads) exhibited Nav1.6 clustering (see also Fig. 3B for Nav1.6 clustering at P60 Scn8atlox/flox CG cells). Images are projections of 21 consecutive optical sections spanning $3.3 \mu \mathrm{m}$. Middle panels, projections of 11 consecutive optical sections spanning $1.7 \mu \mathrm{m}$ in the granular layer showing Nav1.2-positive or Nav1.6-positive (arrowheads) and Nav1.2-negative (arrows) CG cell AISs. Lower panels, deconvolved images showing fragmented Nav1.2 staining (left) and Nav1.6 labelling (right) at P60 CG cell AlSs. Images are deconvolved projection of 7 consecutive optical sections spanning $1 \mu \mathrm{m}$. ml, molecular layer; pkj: Purkinje cell layer; gl: granular layer; wm: white matter. 
protein products, levels of Nav1.6 were examined by in situ immunohistochemical analysis of cerebellar slices at developmental stages where the channel is normally seen at CG cell AISs. At P60, Nav1.6 immunoreactivity was strongly expressed at most CG AISs in $S c n 8 a^{\text {flox } / f l o x}$ mice, whereas it was absent from most CG AISs in Scn8a CG KO mice (Fig. $3 B$ and $C$ ). Nearly $5 \%$ of AISs present in the granular layer remained immunoreactive for anti-Nav1.6 antibodies, possibly due to the non-granule cells present in that layer. In contrast, expression and clustering of Nav1.6 at Purkinje cell AISs were not altered in Scn8a CG KO mice (Fig. $3 B$ and $C$ ). Figure $3 D$ summarizes the percentage of Nav1.6-positive AISs from P10 to adulthood in Scn8a CG KO mice as compared to control mice (pooled data from Scn $8 a^{f l o x} / f l o x$ and WT mice). The percentage of Nav1.6-positive AISs in the granular layer of Scn8a CG KO mice decreased to be virtually undetectable by P38. In contrast, neither Nav1.2 subunit clustering nor expression level appeared affected by the Nav1.6 deletion (Fig. 3D). Nav1.2 subunits were sequestered normally at developing CG cell AISs in Scn8a CG KO and expressed in about 80\% of AISs, as observed in WT animals (Fig. 3D).

Because retinal ganglion cells have been shown to exhibit compensatory $\mathrm{Na}^{+}$channel expression in med mice (Van Wart \& Matthews, 2006), we also examined whether Nav1.1 was present at CG cell AISs, where it is not normally found (Osorio et al. 2005). Double immunolabelling of P60 Scn8a CG KO cerebella with anti-ankyrin $\mathrm{G}$ and anti-Nav1.1 antibodies showed that none of the ankyrin G-positive AISs in the granular layer were immunoreactive for Nav1.1 (Fig. 3E). We confirmed that the Nav1.1 antibody stained AISs of Purkinje cells and inhibitory interneurons in the molecular layer of P19 cerebellum med mice (inset in Fig. 3E), in agreement with Van Wart \& Matthews (2006).

\section{Persistent $\mathrm{Na}^{+}$current is selectively depressed in Scn8a KO mature granule cells}

To assess how the loss of Nav1.6 affects the biophysical properties of $\mathrm{Na}^{+}$currents $\left(I_{\mathrm{Na}}\right)$, we performed a series of voltage-clamp experiments in acute slices of cerebellum from WT and Scn8a CG KO mice aged P66-P74. Voltage-clamp experiments were performed under ionic conditions suitable to isolate $\mathrm{Na}^{+}$currents (see Methods), and current tracings were always TTX-subtracted to better isolate TTX-sensitive $\mathrm{Na}^{+}$currents from contaminants. To elicit transient $\mathrm{Na}^{+}$currents $\left(I_{\mathrm{NaT}}\right)$, an $I-V$ protocol was applied consisting of $20 \mathrm{~ms}$ depolarizing step pulses at -75 to $+20 \mathrm{mV}$ in $5 \mathrm{mV}$ increments. $I_{\mathrm{NaT}}$ thus evoked showed evident signs of bad space-clamp control, especially over the ascending part of the $I-V$ relationship (not shown), very similarly to what has been previously observed for $I_{\mathrm{NaT}}$ of rat CG cells (Magistretti et al. 2006). Such a behaviour is expected for currents generated by channels at least in part located in neuronal processes electrotonically remote from the soma.

The resurgent and persistent $\mathrm{Na}^{+}$currents, $I_{\mathrm{NaR}}$ and $I_{\mathrm{NaP}}$, were elicited by applying a step repolarizing protocol (Fig. $4 A$, top) or ramp depolarizing protocol (Fig. $4 C$, top), respectively, and appeared adequately controlled. Because all $\mathrm{Na}^{+}$-current components showed a tendency to slowly run-up with time, $I_{\mathrm{NaT}}, I_{\mathrm{NaR}}$ and $I_{\mathrm{NaP}}$ activation protocols were repeatedly applied during the course
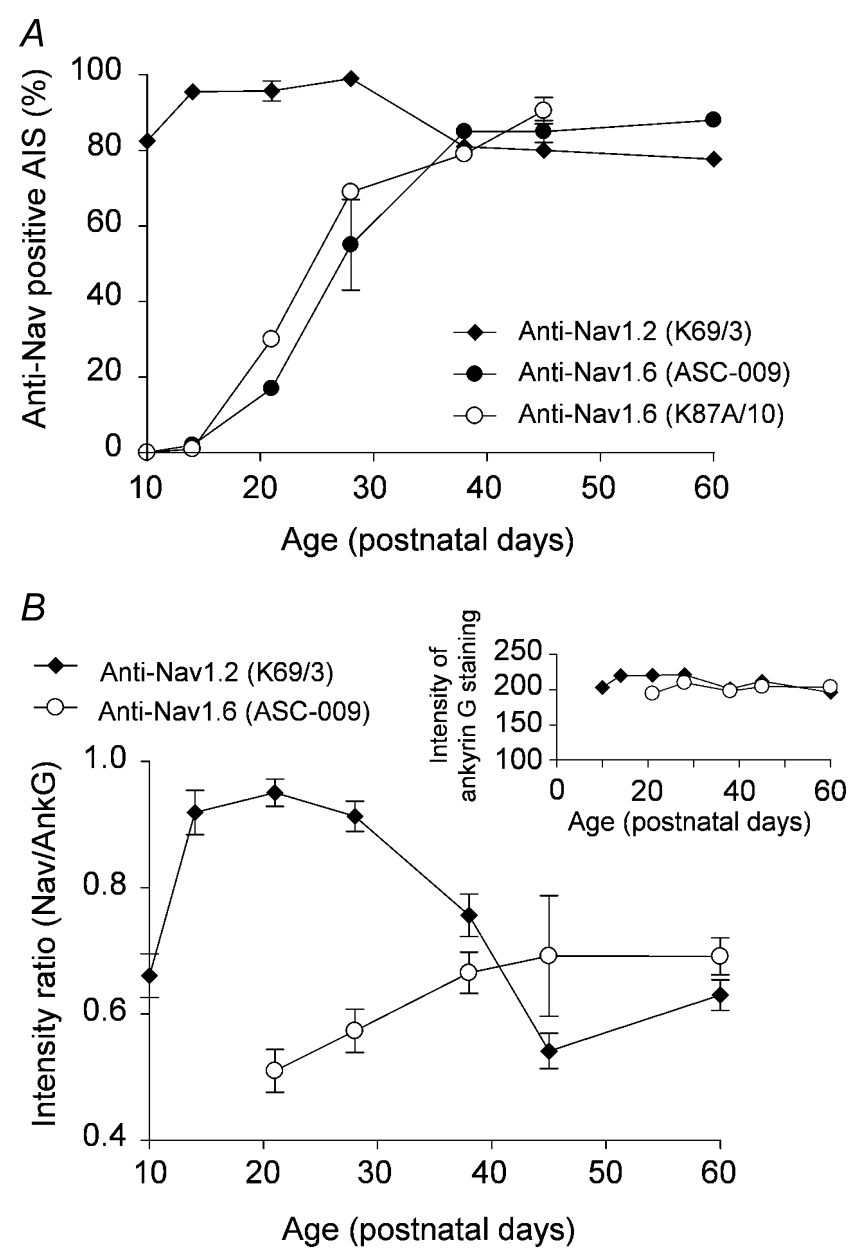

Figure 2. Developmental regulation of Nav1.2 and Nav1.6 clustering at CG cell AISs in mice aged P10-P60

$A$, percentage of total ankyrin G-labelled AISs in the granular layer showing staining for Nav1.2 (monoclonal K69/3 antibody) and Nav1.6 (polyclonal ASC-009 and monoclonal K87A/10) in cerebella from mice aged from P10 to P60. Each data point is the mean \pm S.E.M. of 200 to 500 ankyrin $\mathrm{G}$ positive AISs obtained from at least 3 different animals for each staining condition and developmental stage. $B$,

developmental change in the intensity of Nav1.2 (K69/3 antibody) and Nav1.6 (K87A/10 antibody) immunofluorescence relative to the intensity of ankyrin $\mathrm{G}$ immunostaining at the same AIS. Between 30 and 50 AlSs were measured for each age from Nav1.2/ankyrin G and Nav1.6/ankyrin $\mathrm{G}$ double-labelled confocal images. Inset shows intensity (arbitrary unit) of ankyrin G staining at AISs, which was very much constant over age. 


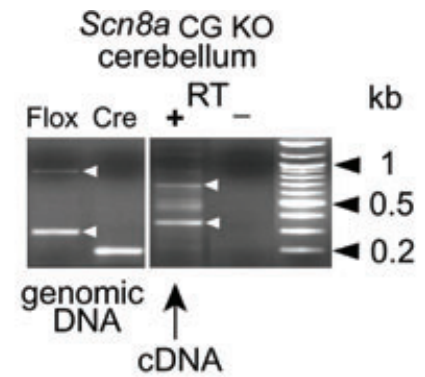

$B$

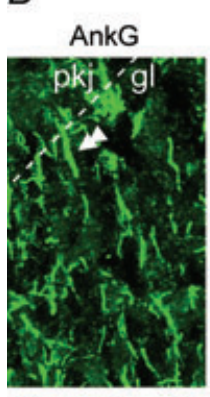

Scn8 $a^{\text {floxfllox }}$ mice
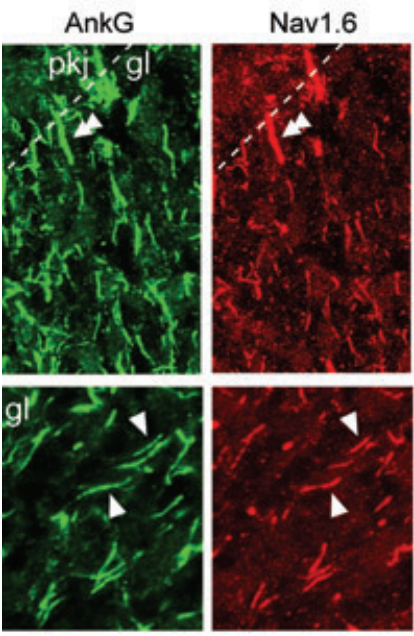

D

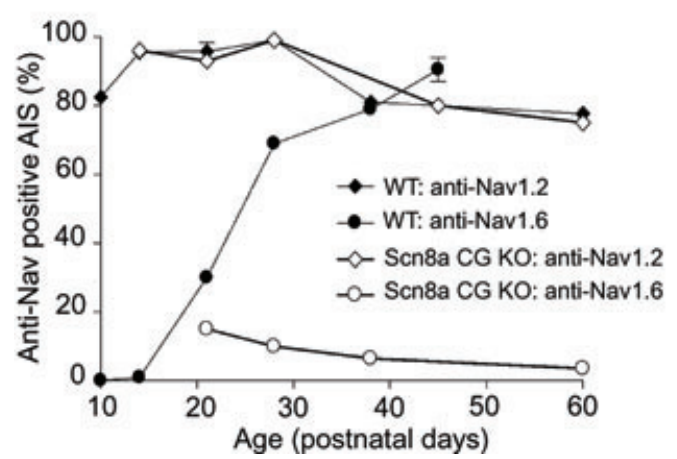

Scn8a CG KO

extra-cerebellar brain

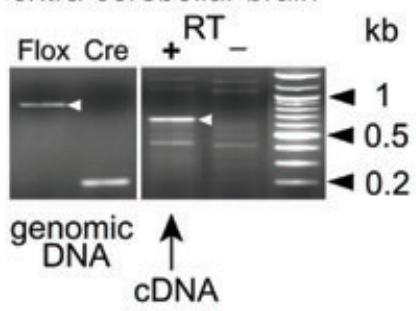

C Scn8a CG KO mice
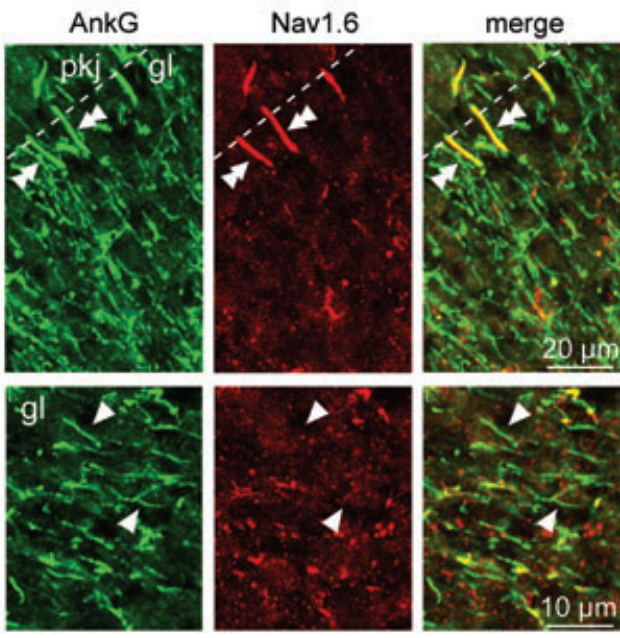

E

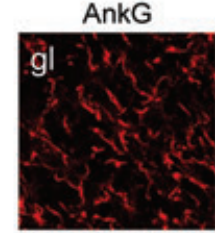

Nav1.1

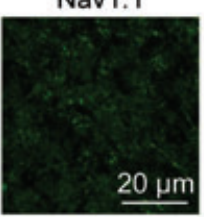

\section{Scn8a CG KO mice}

merge

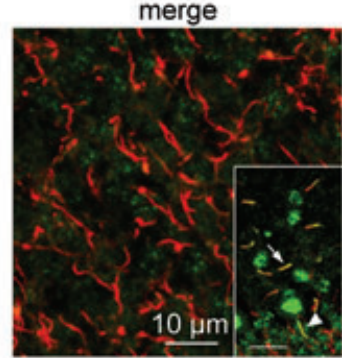

Figure 3. Conditional inactivation of the Scn8a gene in CG cells

A, PCR amplification of genomic DNA and CDNA (obtained from reverse transcription of mRNA) from the cerebellum and extra-cerebellar brain of a Scn8 $a^{\text {flox } / f l o x}-\mathrm{Cre}^{+}(\mathrm{Scn} 8 \mathrm{a}$ CG KO) mouse. Flox primers amplified a $0.9 \mathrm{~kb}$ product from the floxed Scn8a gene and a $0.3 \mathrm{~kb}$ product from the truncated Scn8a, which was detected only in cerebellum. Cre primers amplified a $0.2 \mathrm{~kb}$ product. RT-PCR primers amplified a $0.65 \mathrm{~kb}$ product from the full-length transcripts and a $0.35 \mathrm{~kb}$ fragment from transcripts lacking exon 1 . The $0.35 \mathrm{~kb}$ amplicon was selectively detected in the cerebellum. RT (-) experiments were done omitting reverse transcriptase. $B$ and $C$, cryosections of Scn8aflox/flox $(B)$ and Scn8a KO CG (C) mouse cerebella (aged P60) were double-labelled with anti-ankyrin G (polyclonal) and anti-Nav1.6 (monoclonal K87A/10) antibodies. Scn8aflox/flox CG cell AISs showed strong Nav1.6 staining whereas ankyrin G positive AISs in the granular layer were clearly devoid of Nav1.6 in granule-specific Scn8a KO mice (arrows in C). Note that Purkinje cell AlSs are still positive for Nav1.6 in granule-specific Scn8a KO mice (double arrowheads). Images are projections of 20 consecutive optical sections spanning $3.1 \mu \mathrm{m}$ (upper panels) or 10 sections spanning $1.5 \mu \mathrm{m}$ (bottom panels) in $B$ and $C$. $D$, comparison of proportion of ankyrin G positive CG cell AISs that were positive for Nav1.2 or Nav1.6 in WT mice (data from Fig. 2A; open symbols) and Scn8a CG KO mice (filled symbols) at different ages. Data points for Scn8a CG KO mice are means \pm S.E.M. of 200-300 AISs obtained from at least 2 animals for each staining condition and developmental stage. $E$, cryosections of a P60 Scn8a CG KO mouse cerebellum were double-labelled with anti-ankyrin $\mathrm{G}$ (monoclonal, 4G3F8) and anti-Nav1.1 (polyclonal) antibodies. No Nav1.1 positive AlSs were 
of the experiment, which allowed us to monitor their amplitudes at various moments of the recording (see Fig. 5).

Figure $4 A$ shows currents recorded in response to the $I_{\mathrm{NaR}}$ activation protocol in representative CG cells from WT and Scn8a KO mice. An evident $I_{\mathrm{NaR}}$ was observed in 18 out of 19 CG cells from WT mice, and 14 out of 15 CG cells from $\mathrm{KO}$ mice. In both cases, $I_{\mathrm{NaR}}$ amplitude increased, with increasing repolarizations, up to a peak at -35 to $-40 \mathrm{mV}$, and then decreased for further repolarizations and became particularly fast-decaying at potentials negative to $-50 \mathrm{mV}$. Such a behaviour is characteristic of $I_{\mathrm{NaR}}$ and has been observed in several other neuronal populations (Raman \& Bean, 1997; Do \& Bean, 2003; Afshari et al. 2004; Cummins et al. 2005; Enomoto et al. 2006; Magistretti et al. 2006; Castelli et al. $2007 a, b)$.

To measure $I_{\mathrm{NaR}}$ amplitude, the amplitude of the 'persistent' component observed at the end of the $100 \mathrm{~ms}$ repolarizing pulse (horizontal bars in Fig. 4A) was subtracted from the peak amplitude of the decaying component (see Magistretti et al. 2006). The voltage dependence of $I_{\mathrm{NaR}}$ amplitude was very similar in WT and Scn8a KO CG cells (Fig. 4B). Absolute $I_{\mathrm{NaR}}$ amplitude, measured at the peak of this current's $I-V$ relationship, was, on average, only slightly and not significantly smaller in Scn8a KO CG cells as compared to WT CG cells (Fig. $5 \mathrm{Ba} ; P>0.18$ in all cases). $I_{\mathrm{NaR}}$ amplitude was also evaluated relative to $I_{\mathrm{NaT}}$ amplitude. The amplitude of $I_{\mathrm{NaT}}$ at the peak of its $I-V$ relationship (which in different cells occurred at widely variable voltage values, i.e. -35 to $-10 \mathrm{mV}$ ) was not significantly different in $\mathrm{Scn} 8 \mathrm{a}$ KO and WT CG cells (Fig. 5Aa; $P>0.20$ in all cases). However, it can be expected that measurements of this parameter are strongly influenced by the poor clamp control of $I_{\mathrm{NaT}}$. To attenuate this problem, we considered, as a more significant parameter, $I_{\mathrm{NaT}}$ amplitude at a voltage level positive by $20 \mathrm{mV}$ to the $I-V$ peak $\left(I_{\mathrm{NaT}(\text { peak }+20)}\right)$. Indeed, the currents recorded in the descending portion of $I_{\mathrm{NaT}}$ 's $I-V$ relationship are expected to be less affected by clamp artifacts than those recorded in the ascending and peak regions (discussed in Castelli et al. 2007b). $I_{\mathrm{NaT}(\text { peak }+20)}$ was also not significantly different in Scn8a KO and WT CG cells (Fig. $5 A b ; P>0.12$ in all cases). Expressing $I_{\mathrm{NaR}}$ peak amplitude relative to $I_{\mathrm{NaT}(\text { peak }+20)}$ (the temporally closest pairs of $I_{\mathrm{NaR}}$ and $I_{\mathrm{NaT}}$ recordings were always considered to calculate this ratio) further reduced the slight, non-significant differences observed for $I_{\mathrm{NaR}}$ absolute amplitude $(P>0.10$ at $1.5-4 \mathrm{~min}, P>0.4$ at the other time points; Fig. $5 B b$ ).
$I_{\mathrm{NaR}}$ kinetics was also compared between WT and KO CG cells. For these measurements, $I_{\mathrm{NaR}}$ recordings obtained in individual cells at different time points were averaged, so as to improve the signal-to-noise ratio and the reliability of measures. First, the activation kinetics of $I_{\mathrm{NaR}}$ was evaluated by measuring the current's time to peak (TTP) at the different voltage levels examined. As shown in Fig. 6A, TTP progressively increased from $\sim 3.5 \mathrm{~ms}$ at $-15 \mathrm{mV}$ to $\sim 5.5 \mathrm{~ms}$ at -30 to $-40 \mathrm{mV}$, and decreased back sharply at potentials negative to $-50 \mathrm{mV}$. At potentials negative to $-60 \mathrm{mV}, I_{\mathrm{NaR}}$ activation was so fast that no current peak clearly separated from the foregoing tail currents and/or unsubtracted artifacts by a rising phase was distinguishable, and TTP could not be measured. It can be seen that TTP absolute values and TTP voltage dependence were extremely similar in $\mathrm{WT}$ and $\mathrm{KO}$ CG cells (Fig. 6A). $I_{\mathrm{NaR}}$ kinetics was further characterized by performing exponential fittings of the current rising and decay phases. Both phases could be consistently fitted jointly by applying a double exponential function (Fig. $6 B$, upper and middle tracings). Increasing the number of the exponential components did not improve the goodness of fit. At potentials negative to $-50 \mathrm{mV}, I_{\mathrm{NaR}}$ rising phase was too short or indistinguishable, and a single exponential function was only applied to fit $I_{\mathrm{NaR}}$ decay phase (Fig. $6 B$, lower tracing). The voltage dependence of the time constant of $I_{\mathrm{NaR}}$ activation $\left(\tau_{\text {act }}\right)$ closely paralleled that of TTP (Fig. $6 \mathrm{Ca}$ ). The time constant of $I_{\mathrm{NaR}}$ decay $\left(\tau_{\text {decay }}\right)$ displayed a behaviour very similar to that previously reported for $I_{\mathrm{NaR}}$ of rat CG cells (Magistretti et al. 2006), including a nearly plateau level at -30 to $-50 \mathrm{mV}$, a sharp decrease at more negative voltages, and a trend to increase at potentials positive to $-25 \mathrm{mV}$ (Fig. $6 \mathrm{Cb}$ ). Moreover, $\tau_{\text {decay }}$ turned out to be very similar between WT and KO CG cells over the whole voltage range explored (Fig. $6 \mathrm{Cb}$ ). Hence, $\mathrm{KO}$ of the $\mathrm{Na}_{\mathrm{v}} 1.6$ subunit has no apparent effects on the kinetics of the resurgent sodium current expressed by CG cells.

The persistent $\mathrm{Na}^{+}$current, $I_{\mathrm{NaP}}$, was evoked by applying slow depolarizing ramps with a slope of $0.1 \mathrm{mV} \mathrm{ms}^{-1}$ (Fig. 4C) and $0.05 \mathrm{mV} \mathrm{ms}^{-1}$ (not shown), which allowed us to obtain 'instantaneous' $I-V$ relationships for $I_{\mathrm{NaP}}$. The currents evoked by $0.05 \mathrm{mV} \mathrm{ms}^{-1}$ ramps were consistently smaller in amplitude than those evoked by $0.1 \mathrm{mV} \mathrm{ms}^{-1}$ ramps (Fig. $5 \mathrm{Ca}$ ), indicating the development of $I_{\mathrm{NaP}}$ inactivation during slow depolarizations (see Fleidervish \& Gutnick, 1996; Magistretti \& Alonso, 1999; Osorio et al. 2005). Plots of $I_{\mathrm{NaP}}$ voltage dependence of activation were obtained from 'instantaneous' $I-V$ relationships by deriving $\mathrm{Na}^{+}$

detected in the granular layer. Images are projections of 21 consecutive optical sections spanning $3.3 \mu \mathrm{m}$. Inset: staining of AISs of Purkinje cells (arrowhead) and inhibitory interneurons (arrow) for Nav1.1 (green) and ankyrin G (red) from P19 med cerebellum. Scale bar: $20 \mu \mathrm{m}$. 
Aa
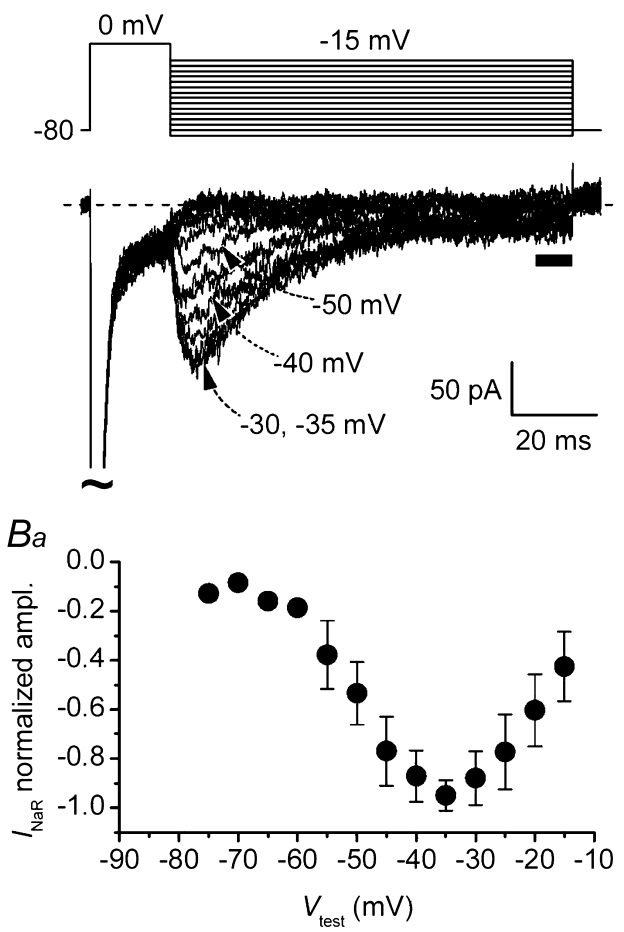

Ca
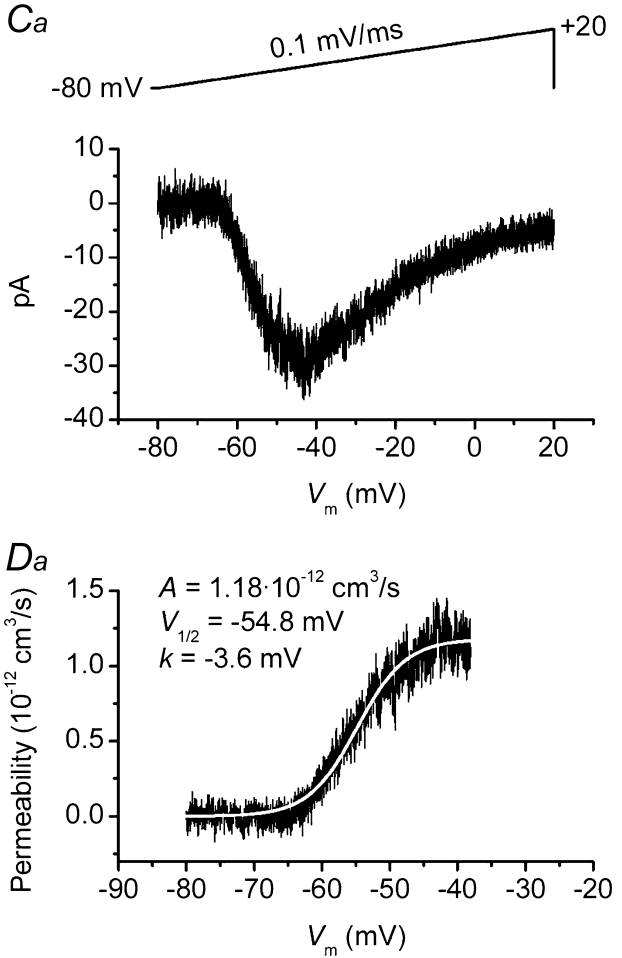

$b$ Scn8a KO
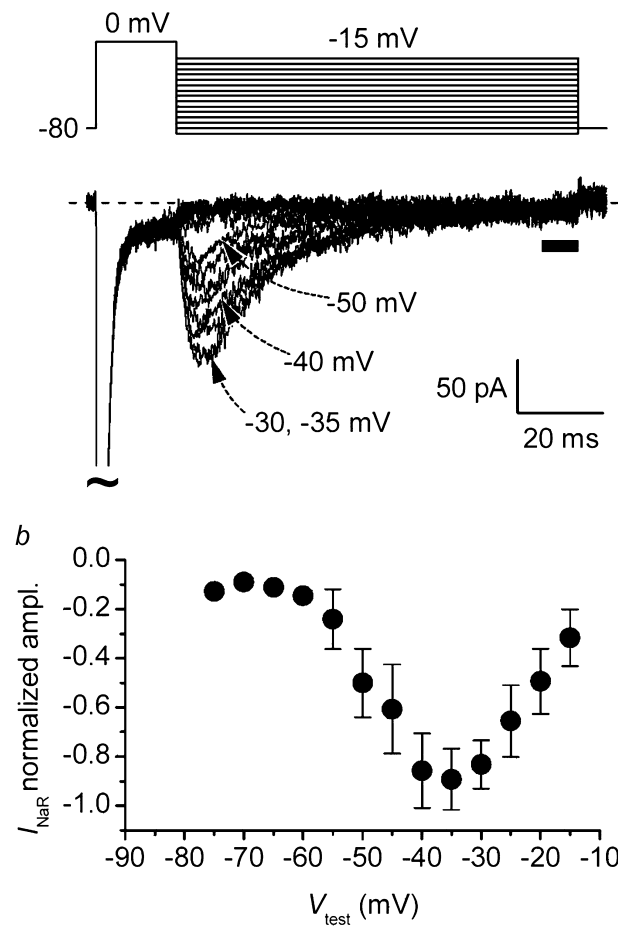

$b$
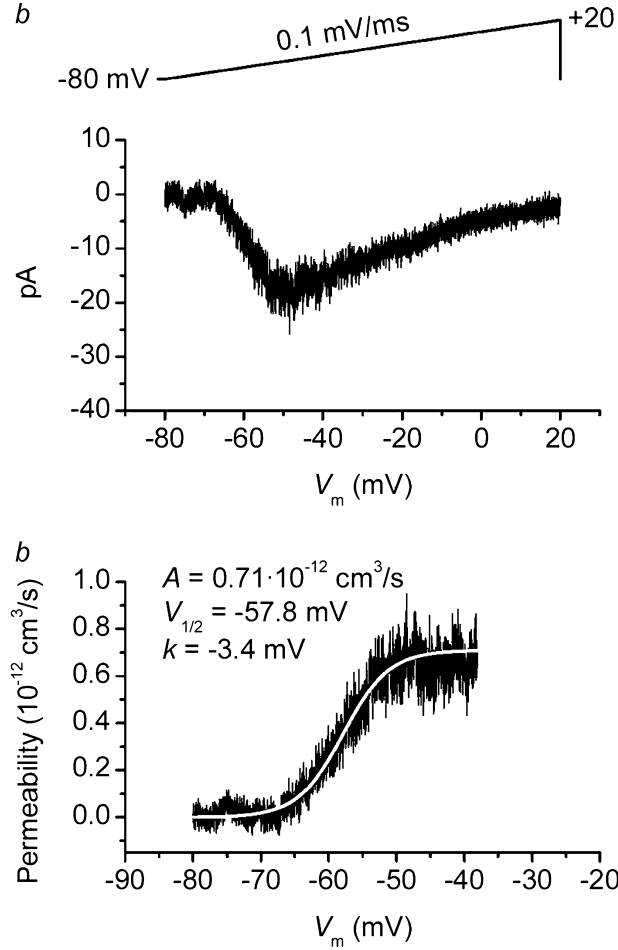

Figure 4. Resurgent and persistent $\mathrm{Na}^{+}$currents in CG cells from wild-type (left) and Scn8a CG KO (right) mice

$A$, currents recorded in response to an $/$ NaR activation protocol (upper subpanels) in a representative WT CG cell (cell C8514; a) and a representative Scn8a KO CG cell (cell H8509; b). Transient $\mathrm{Na}^{+}$currents elicited by the test depolarization at $0 \mathrm{mV}$ have been truncated $(\sim)$. The horizontal bars indicate the tracing region over which current data points were averaged to measure the amplitude of the sustained component $\left(I_{\mathrm{NaP}}\right)$, which was subtracted from the peak amplitude of the transient current elicited by repolarizing pulses to obtain a measurement of $/_{\mathrm{NaR}}$ amplitude. $B$, average $I_{\mathrm{NaR}}$ current-voltage $(I-V)$ plots for WT CG cells $(a)$ and Scn8a KO CG cells $(b)$. The plots were obtained from currents recorded 6-9.5 min after break-in. / NaR peak amplitudes were normalized for the maximal 

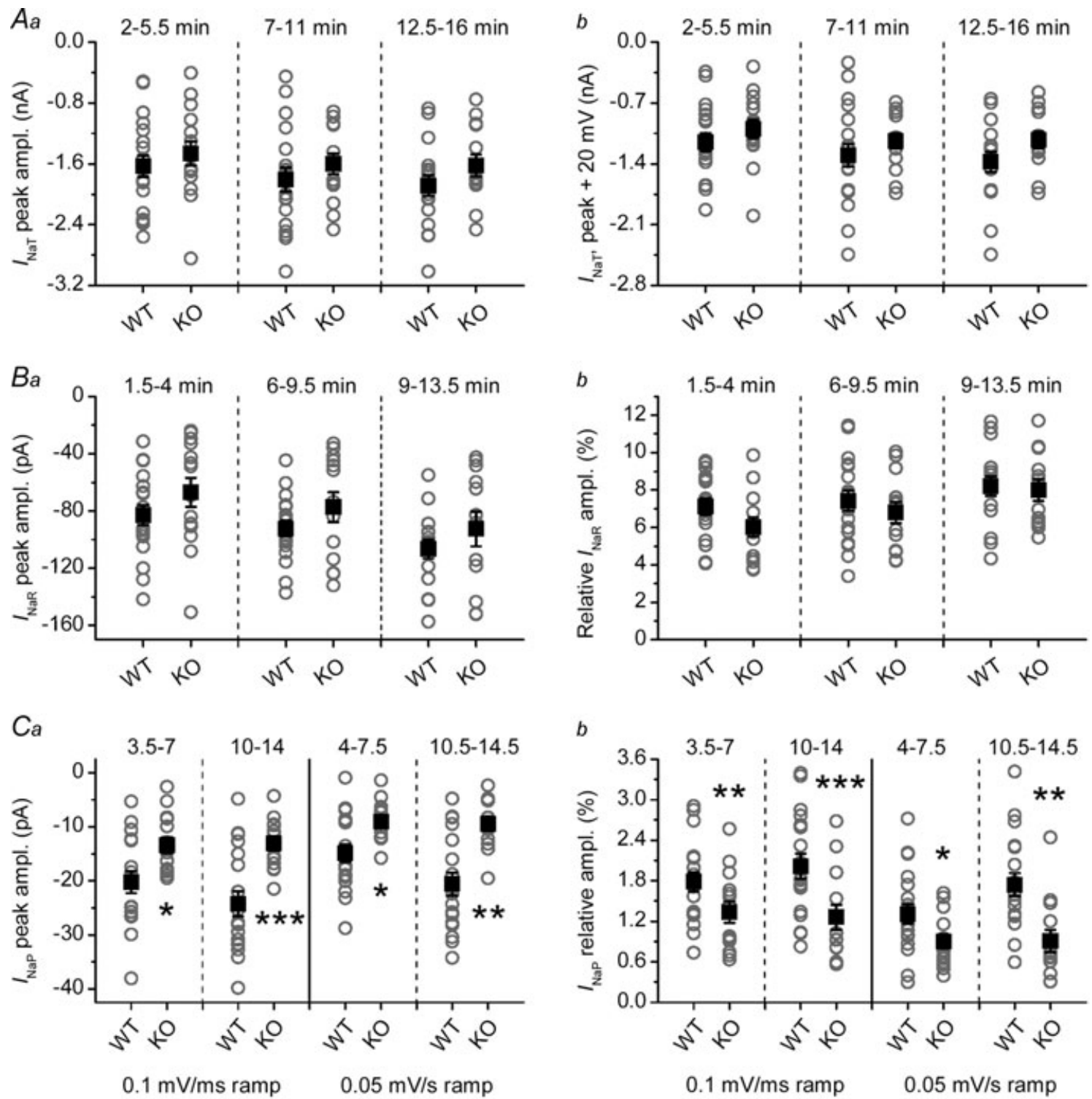

Figure 5. Amplitude of transient, resurgent, and persistent $\mathrm{Na}^{+}$currents in CG cells from wild-type and Scn8a CG KO mice

Each panel shows amplitude values for $I_{\mathrm{NaT}}(A), I_{\mathrm{NaR}}(B)$, and $I_{\mathrm{NaP}}(C)$ as determined at various time points after break-in (see the labels at the top of each subpanel). The parameters considered are: $I_{\mathrm{NaT}}$ absolute amplitude at the peak of its $I-V\left(I_{\text {NaT (peak }) ; ~} A a\right) ; I_{\text {NaT }}$ absolute amplitude at a voltage level positive by $20 \mathrm{mV}$ to the $I-V$ peak $\left(I_{\mathrm{NaT}(\text { peak }+20) ;} ; b\right) ; I_{\mathrm{NaR}}$ absolute amplitude at the peak of its $I-V(B a) ; I_{\mathrm{NaR}}$ peak amplitude relative to $I_{\text {NaT (peak }+20)}$ amplitude (as a percentage; $B$ b); absolute, peak amplitude of ramp-evoked $I_{\mathrm{NaP}}(\mathrm{Ca})$; peak amplitude of ramp-evoked $I_{\mathrm{NaP}}$ relative to $I_{\mathrm{NaT}(\text { peak }+20)}$ amplitude (as a percentage; $C$ b). Note in $C$ that both $0.1 \mathrm{mV} \mathrm{ms}^{-1}$ and $0.05 \mathrm{mV} \mathrm{ms}^{-1}$ ramps were applied to measure $/ \mathrm{NaP}$ amplitude (left and right parts of each subpanel, respectively). Open circles are individual values; filled squares indicate mean values \pm S.E.M.

value observed in each cell, then averaged among cells. Data points and error bars are means \pm S.D. $(n=12$ and 11 in $B a$ and $B b$, respectively). C, currents recorded in response to a ramp / Nap activation protocol (upper subpanels) in a representative WT CG cell (Ca) and a representative Scn8a KO CG cell (Cb) (same cells as shown in $A a$ and $A b$, respectively). In the lower subpanels the currents are shown as 'instantaneous' $I-V$ relationships. $D$, voltage dependence of the $\mathrm{Na}^{+}$permeability underlying the ramp-activated $/{ }_{\text {NaP }}$ values shown in $\mathrm{Ca}$ and $\mathrm{Cb}$. $\mathrm{Na}^{+}$-permeability values were obtained from current values by applying the Goldman equation as explained in Methods. Continuous white lines are best fits obtained by applying a single Boltzmann function. Fitting parameters are specified in each panel. 
permeability values $\left(P_{\mathrm{NaP}}\right)$ from $\mathrm{Na}^{+}$currents as explained in Methods (Fig. $4 D$ ). Fitting $P_{\mathrm{NaP}}(V)$ plots with a single Botzmann function (Fig. $4 D$ ) returned average half-activation potential $\left(V_{1 / 2}\right)$ and slope factor $(k)$ values that were not significantly different in Scn8a KO and WT CG cells (Table 1). However, $I_{\mathrm{NaP}}$ peak amplitude was significantly smaller, by a factor of $\sim 1.5$ to 2.2 , in $S c n 8$ a KO CG cells as compared to WT CG cells (Fig. 5Ca). Peak $I_{\mathrm{NaP}}$ amplitude relative to $I_{\mathrm{NaT}(\text { peak }+20)}$ was also significantly smaller (by $\sim 1.35-1.9$ times) in Scn8a KO CG cells (Fig. 5Cb).

\section{Scn8a KO CG cells have impaired firing regularity}

To test how the loss of Nav1.6 affects the firing properties of CG cells, we performed a series of current-clamp experiments in acute slices of cerebellum from WT and Scn8a CG KO mice aged P40-P65. To characterize intrinsic membrane properties, we examined the response of CG cells to constant current injection (Fig. 7A). Passive properties (input capacitance, input conductance and resting membrane potential) of WT and Scn8a KO CG cells were not significantly different (Table 2).
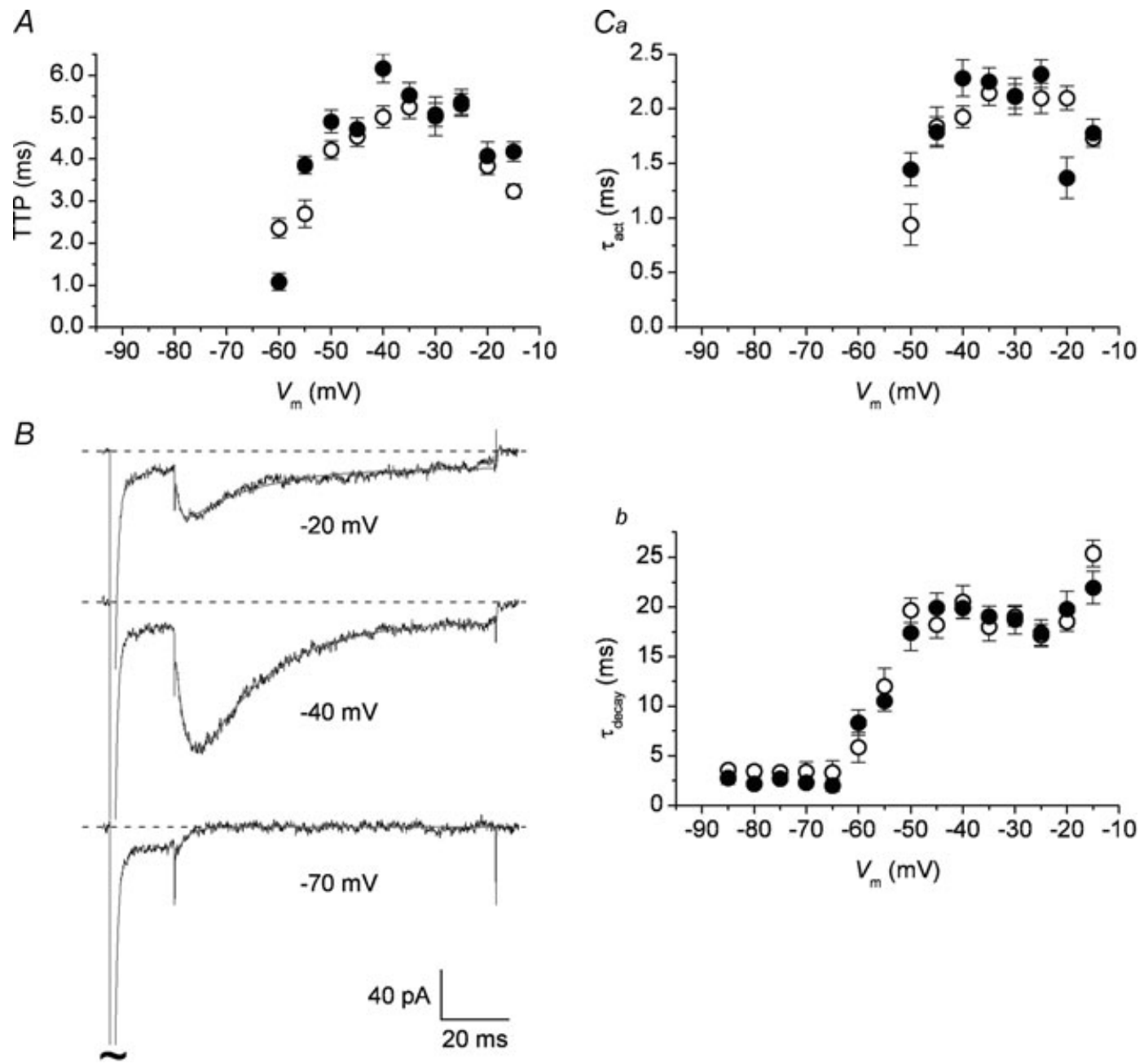

Figure 6. INaR activation kinetics is not affected by Scn8a knockout

$A$, voltage dependence of $I_{\text {NaR }}$ time to peak (TTP) in WT (open circles) and Snc8a KO (filled circles) CG cells $(n=15$ and 13 for WT and KO, respectively). B, currents recorded in response to the / $/$ ar activation protocol (see Fig. $4 A$ ) at three different repolarisation potentials $(-20,-40$ and $-70 \mathrm{mV}$ ) in a representative WT neuron (cell A8514), and biexponential fittings (enhanced lines) of $I_{\mathrm{NaR}}$ activation and decay phases. Fitting parameters are: $A_{1}=37.6 \mathrm{pA}, \tau_{1}=1.33 \mathrm{~ms}, A_{2}=-50.1 \mathrm{pA}, \tau_{2}=21.3 \mathrm{~ms}, C=-13.2 \mathrm{pA}(-20 \mathrm{mV})$; $A_{1}=130.0 \mathrm{pA}, \quad \tau_{1}=3.25 \mathrm{~ms}, A_{2}=-166.3 \mathrm{pA}, \tau_{2}=20.2 \mathrm{~ms}, C=-15.4 \mathrm{pA}(-40 \mathrm{mV}) ; A_{2}=-24.0 \mathrm{pA}$, $\tau_{2}=2.88 \mathrm{~ms}, C=0.0 \mathrm{pA}(-70 \mathrm{mV}) . C$, voltage dependence of $I_{\mathrm{NaR}}$ activation time constant, $\tau_{\text {act }}$ (equivalent to panel B's $\left.\tau_{1}\right)(C a)$, and / NaR decay time constant, $\tau_{\text {decay }}$ (equivalent to panel B's $\left.\tau_{2}\right)(C b)$, in WT (open circles) and Snc8a KO (filled circles) CG cells ( $n=15$ and 13 for WT and KO, respectively). 
Table 1. I $I_{\text {NaP }}$ activation parameters

\begin{tabular}{|c|c|c|c|c|c|c|c|c|c|c|}
\hline & \multicolumn{5}{|c|}{ Time point: $3.5-7.5 \mathrm{~min}$} & \multicolumn{5}{|c|}{ Time point: $10-14.5 \mathrm{~min}$} \\
\hline & \multicolumn{2}{|l|}{ WT } & \multicolumn{2}{|c|}{ Scn8a KO } & \multirow[b]{2}{*}{$P$} & \multicolumn{2}{|l|}{ WT } & \multicolumn{2}{|c|}{ Scn8a KO } & \multirow[b]{2}{*}{$P$} \\
\hline & mean \pm S.D. & $n$ & mean \pm S.D. & $n$ & & mean \pm S.D. & $n$ & mean \pm S.D. & $n$ & \\
\hline \multicolumn{11}{|c|}{$0.1 \mathrm{Vs}^{-1}$} \\
\hline$V_{1 / 2}$ & $-55.9 \pm 3.4$ & 15 & $-56.0 \pm 4.5$ & 6 & 0.96 & $-59.7 \pm 2.8$ & 15 & $-60.6 \pm 3.9$ & 6 & 0.59 \\
\hline$k$ & $-3.6 \pm 0.7$ & & $-3.0 \pm 0.4$ & & 0.08 & $-3.5 \pm 0.6$ & & $-3.0 \pm 0.6$ & & 0.15 \\
\hline \multicolumn{11}{|c|}{$0.05 \mathrm{Vs}^{-1}$} \\
\hline$V_{1 / 2}$ & $-56.7 \pm 2.7$ & 15 & $-56.5 \pm 3.2$ & 6 & 0.87 & $-59.7 \pm 2.8$ & 15 & $-60.7 \pm 3.2$ & 6 & 0.49 \\
\hline$k$ & $-3.9 \pm 0.8$ & & $-3.5 \pm 0.9$ & & 0.33 & $-3.9 \pm 1.1$ & & $-3.1 \pm 0.6$ & & 0.11 \\
\hline
\end{tabular}

The table shows $I_{\mathrm{NaP}}$ activation parameters $\left(V_{1 / 2}\right.$ and $k$, in $\left.\mathrm{mV}\right)$ returned by Boltzmann fittings of $P_{\mathrm{NaP}}(V)$ plots. Statistical comparisons were made applying Student's two-tail $t$ test for unpaired data.

Table 2. Intrinsic membrane properties and action potential (AP) characteristics measured in WT and Scn8a KO CG cells

\begin{tabular}{|c|c|c|c|c|c|}
\hline & \multicolumn{2}{|c|}{ WT } & \multicolumn{2}{|c|}{ Scn8a KO } & \multirow[b]{2}{*}{$P$} \\
\hline & mean \pm S.E.M. & $n$ & mean \pm S.E.M. & $n$ & \\
\hline Input capacitance (pF) & $3.9 \pm 0.2$ & 23 & $3.9 \pm 0.3$ & 17 & $>0.05$ \\
\hline Input conductance (pS) & $0.7 \pm 0.1$ & 21 & $0.8 \pm 0.1$ & 15 & $>0.05$ \\
\hline Resting membrane potential (mV) & $-92.5 \pm 1.6$ & 11 & $-94.1 \pm 1.3$ & 13 & $>0.05$ \\
\hline AP threshold (mV) & $-42.4 \pm 1$ & 23 & $-42.8 \pm 0.9$ & 17 & $>0.05$ \\
\hline AP overshoot $(\mathrm{mV})$ & $22.5 \pm 2$ & 23 & $21.2 \pm 2$ & 17 & $>0.05$ \\
\hline AP rise time (ms) & $0.42 \pm 0.02$ & 23 & $0.33 \pm 0.01$ & 16 & $<0.05$ \\
\hline AP half-width (ms) & $0.67 \pm 0.02$ & 23 & $0.51 \pm 0.02$ & 16 & $<0.05$ \\
\hline Postspike AHP (mV) & $-71.6 \pm 0.7$ & 23 & $-74.9 \pm 0.8$ & 17 & $<0.05$ \\
\hline
\end{tabular}

Statistical comparisons were made applying Student's two-tail $t$ test for unpaired data.

Subthreshold $I-V$ relationships of both WT and Scn8a KO CG cells exhibited moderate inward rectifications, typical of mature CG cells (Fig. 7A; Cathala et al. 2003). The current required to reach firing threshold was also not significantly different between the two conditions (Table 2 and Fig. $7 B$ ). Figure $7 D$ shows superimposed representative action potentials obtained from WT and Scn8a KO cells. Action potential threshold and overshoot (Table 2 and Fig. $7 D$ ) were identical in the WT and Scn8a KO CG cells. However, both AP rise time and half-width were significantly reduced in Scn8a KO CG cells (WT CG cells: rise time $=0.42 \pm 0.02 \mathrm{~ms}$, half-width $=0.67 \pm 0.02 \mathrm{~ms}$; Snc8a KO CG cells: rise time $=0.33 \pm 0.01 \mathrm{~ms}$, half-width $=0.51 \pm 0.02 \mathrm{~ms}$; Table 2). Moreover, a significant enhancement of the postspike AHP was typically observed in Scn8a KO CG cells compared to WT CG cells (Fig. $7 G$ and Table 2). When considering the AHP that followed the first spike obtained in response to the minimum injected current which evoked firing, AHP peak was at $-74.9 \pm 0.8 \mathrm{mV}$ in $\operatorname{Scn} 8$ a KO CG cells vs. $-71.6 \pm 0.7 \mathrm{mV}$ in WT CG cells $(P<0.05$; Table 2). Similar differences and statistical significance were observed when comparing the postspike AHP at 40 or $100 \mathrm{~Hz}$ firing frequency.

In agreement with previous studies, mature CG cells supported high-frequency firing in response to sustained depolarization. Figure $7 C$ shows representative examples of firing responses to injection of increasing amounts of current in WT and Scn8a KO CG cells. There was a tendency toward reduction in the mean firing frequency of Scn8a KO CG cells (Fig. 7I), resulting in a reduction in the gain of the frequency-stimulation relationship (slopes of the frequency-current plots: $1.72 \pm 0.04$ in WT vs. $1.17 \pm 0.03 \mathrm{~Hz} \mathrm{pA}^{-1}$ in Scn8a KO CG cells). AP firing was more variable in Scn8a KO than in WT, as shown by the difference in the shape of interspike interval (ISI) distribution (Kolmogorov-Smirnov test, $P<0.001$; Fig. $7 H$ ). The slope of the cumulative plot for small ISI durations was higher in Scn8a KO CG cells than in WT cells, whereas it was lower for longer ISI durations (Fig. $7 \mathrm{H}$ ). These results indicate that firing was less regular in Scn8a KO CG cells, thus implying that Nav1.6 is necessary to maintain regular spiking.

\section{Discussion}

\section{Developmental regulation of Nav isoforms in mouse cerebellar granule cells in situ}

The present study provides evidence that expression of Nav1.2 and Nav1.6 subunits in mouse CG cells in situ is developmentally regulated. Nav1.2 subunits were detected 
$A$
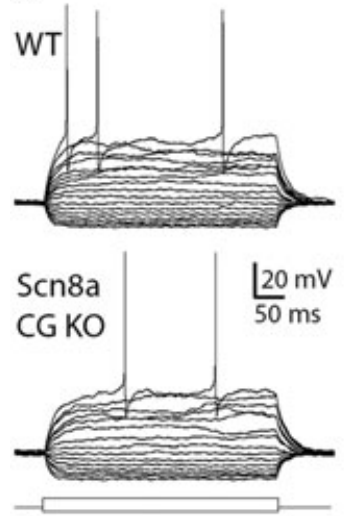

$D$

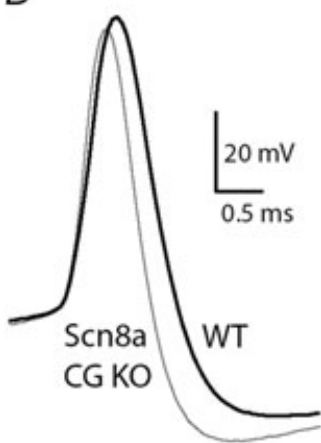

$B$

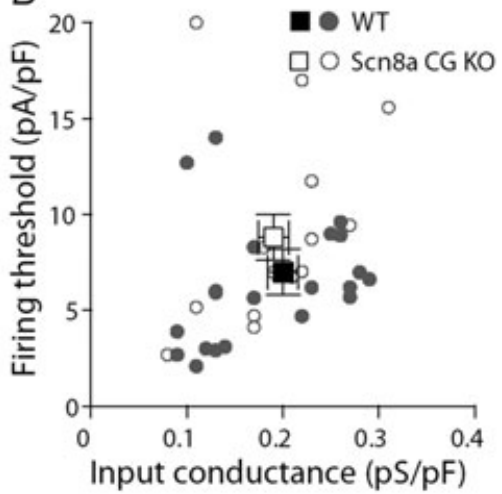

E

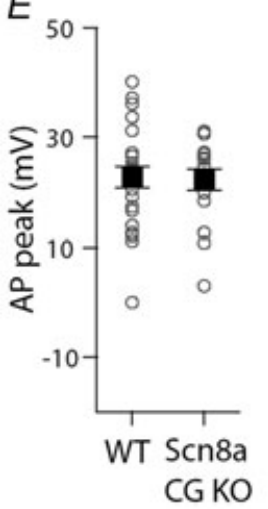

$F$
C
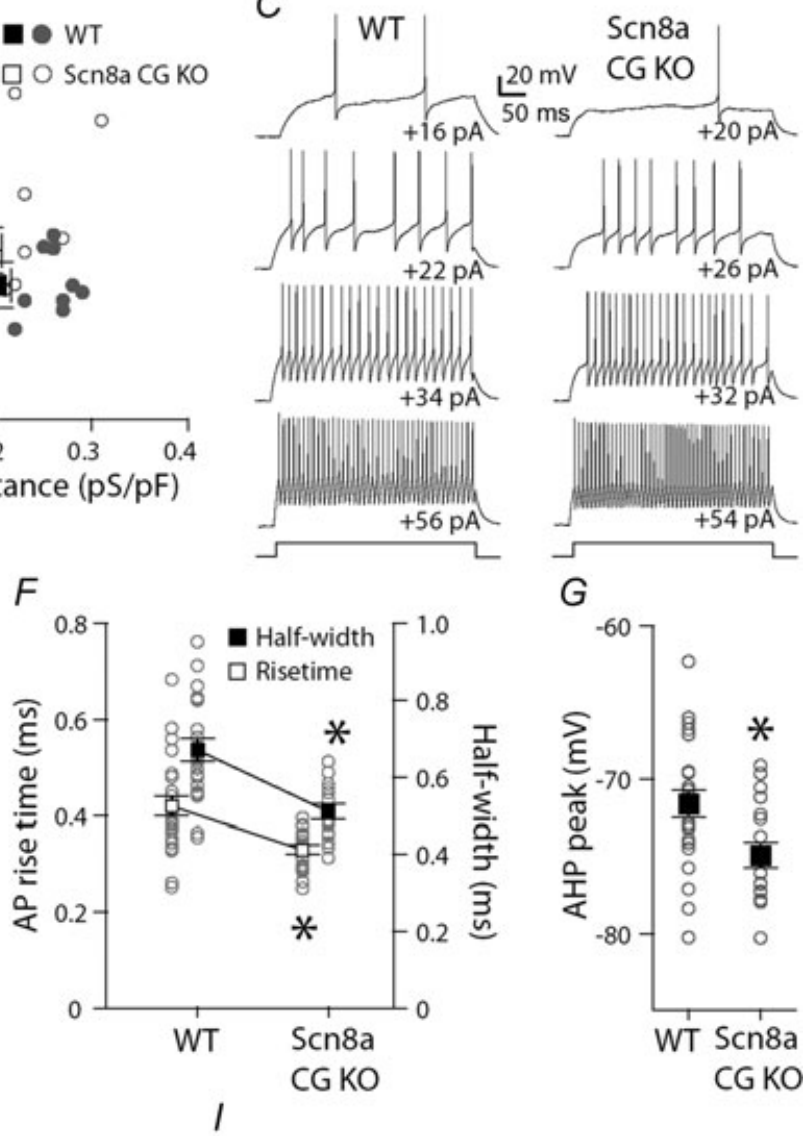

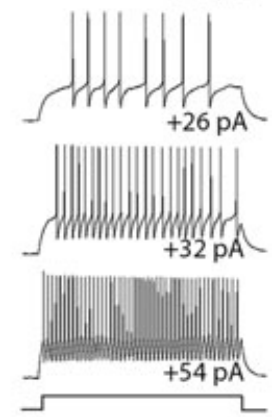

G

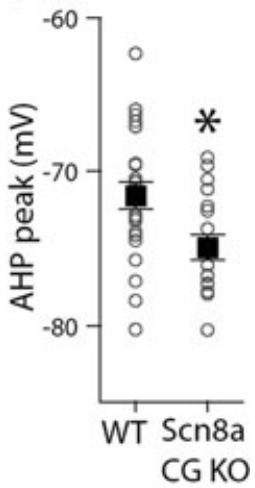

$H$
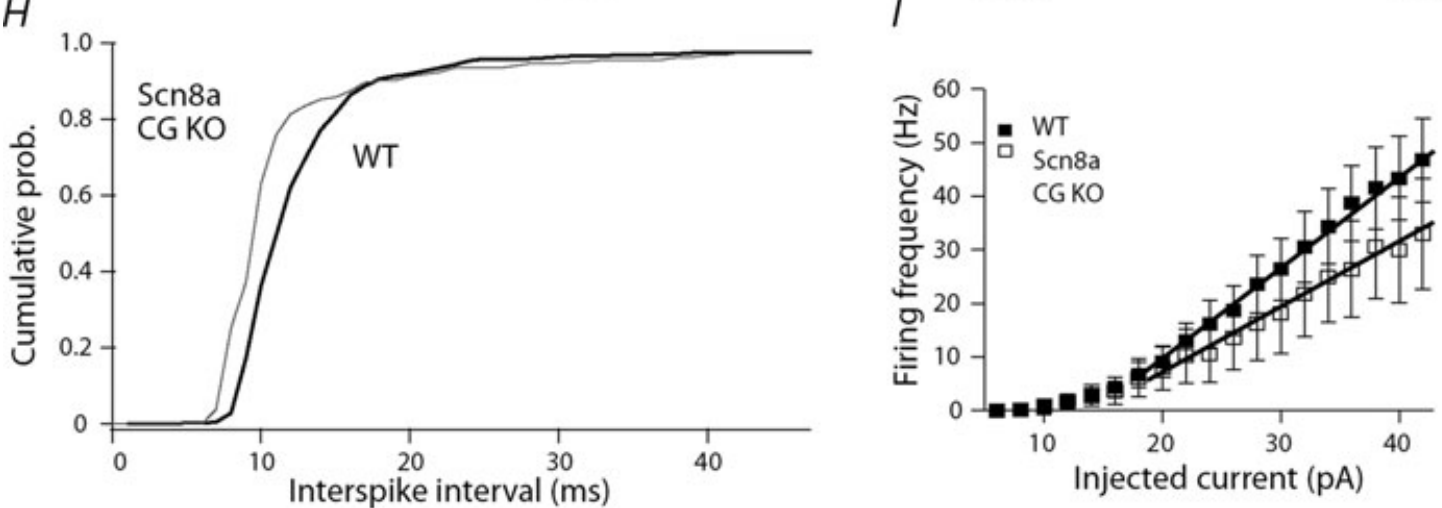

Figure 7. Passive and firing properties of CG cells from wild-type and Scn8a CG knockout mice A, characteristic responses of CG cells from WT (P37) and Snc8a CG KO (P59) mice to current injection (2 pA step increments). Shown are passive electrotonic responses to hyperpolarizing current pulse injections and responses up to the first current step that induced spiking in each cell. $B$, relationship between input conductance and firing threshold (the minimal current required to evoke action potentials) in WT ( $n=21)$ and Scn8a KO CG cells $(n=15$; $P>0.05$ ). Circles indicate individual values and squares indicate mean values \pm S.E.M. (WT: filled symbols; Snc8a CG KO: open symbols.) D, characteristic action potentials from WT (black line, P49) and Snc8a CG KO (grey line, P41) mice. Shown are the first recorded action potentials aligned at threshold. The WT action potential has a rise time of $0.35 \mathrm{~ms}$, a peak amplitude of $31.3 \mathrm{mV}$ and a half-width of $0.64 \mathrm{~ms}$ while the $S \mathrm{nc} 8 \mathrm{a}$ CG KO action potential has a rise time of $0.29 \mathrm{~ms}$, a peak amplitude of $32.0 \mathrm{mV}$ and a half-width of $0.50 \mathrm{~ms}$. E, action potential peak in CG cells from WT mice $(+22.5 \pm 2.0 \mathrm{mV}, n=23)$ and Snc8a CG KO mice $(+21.2 \pm 2.0 \mathrm{mV}, n=17)(P>0.05)$. Open circles indicate individual values; filled squares indicate mean values \pm S.E.M. $F$, action potential rise time (filled squares) in CG cells from WT mice $(0.42 \pm 0.02 \mathrm{~ms}, n=23)$ and Snc8a CG KO mice $(0.33 \pm 0.01 \mathrm{~ms}$, $n=16)$ and half-width (open squares) in CG cells from WT mice $(0.67 \pm 0.02 \mathrm{~ms}, n=23)$ and Snc8a CG KO mice $(0.51 \pm 0.02 \mathrm{~ms}, n=16)$. Open circles indicate individual values; filled squares indicate mean values \pm S.E.M. $G$, postspike AHP amplitude in CG cells from WT mice $(-71 \pm 0.7 \mathrm{mV}, n=17)$ and Snc8a CG KO mice $(-74.9 \pm 0.8 \mathrm{mV}, n=23)$. Open circles indicate individual values; filled squares indicate mean values \pm s.E.M. C, 
at most CG cell AISs from the early stages of maturation to adulthood with a sparser distribution in mature CG cell AISs as compared to the first postnatal stages. In contrast Nav1.6 expression at the AISs appears much later, once CG cells have attained their mature electrophysiological phenotype (D'Angelo et al. 1997; Cathala et al. 2003). Our data also suggest that the mechanisms responsible for selective targeting of Nav1.6 to the AISs do not exclude Nav1.2 from this site. Thus, as with AISs of retinal ganglion cells (Boiko et al. 2003), but unlike nodes of Ranvier in the myelinating optic nerve (Boiko et al. 2001), Nav1.2 expression does not disappear from CG cell AISs as Nav1.6 expression increases, indicating that in CG cells both subunits participate to define the characteristics of mature $\mathrm{Na}^{+}$currents.

\section{Contribution of Nav1.6 and Nav1.2 to transient, resurgent and persistent $\mathrm{Na}^{+}$currents}

The biophysical properties of CG cell $I_{\mathrm{NaR}}$ were similar to those described for $I_{\mathrm{NaR}}$ in rat CG cells in situ (Magistretti et al. 2006) and in acutely dissociated mice CG cells (Afshari et al. 2004). It displayed a bell-shaped voltage dependence with a peak at $-35 /-40 \mathrm{mV}$. In Purkinje cells, $I_{\mathrm{NaR}}$ has been primarily ascribed to the activity of Nav1.6 channels (Raman et al. 1997; Levin et al. 2006; Royeck et al. 2008). However, it is becoming clear that other $\mathrm{Na}^{+}$ channel subunits, including Nav1.2 (Rush et al. 2005) and Nav1.1 (Grieco \& Raman, 2004), may also contribute to $I_{\mathrm{NaR}}$ in some neurons (Do \& Bean, 2004; Enomoto et al. 2007). Consistent with this view, we found that in Scn8a KO CG cells, $I_{\mathrm{NaR}}$ amplitude levels were unchanged with respect to WT cells. Interestingly, $I_{\mathrm{NaR}}$ activation and decay kinetics were also indistinguishable in Scn8a KO CG cells as compared to WT cells. This is different from what has been reported for Purkinje cells, in which a slowing of activation and decay kinetics of residual $I_{\mathrm{NaR}}$ has been observed in Nav1.6-null mice (Aman \& Raman, 2007). Our results clearly show that the Nav1.2 subunit is capable of generating a resurgent current which appears fully normal in terms of both amplitude and kinetic properties, at least in particular conditions. They also may imply that Nav1.6 channels normally do not contribute to $I_{\mathrm{NaR}}$, or, alternatively, that they can be fully substituted by Nav1.2 channels, as far as $I_{\mathrm{NaR}}$ generation is concerned, when Nav1.6 expression is impaired. Which one of these two possibilities is correct cannot be inferred on the basis of the present findings.

Our data raise another open question regarding the basis of the resurgence mechanism itself. Recently, it has been shown that in Purkinje cells the cytoplasmic tail of the $\mathrm{Na}^{+}$channel auxiliary $\beta 4$ subunit can act as the 'resurgent particle' by competing with the inactivation ball domain of the $\mathrm{Na}^{+}$channel $\alpha$ subunit (Grieco et al. 2005). However, the auxiliary $\beta 4$ subunit is expressed at detectable levels neither in rat (Yu et al. 2003) nor in mouse (Allen Brain Atlas, www.brain-map.org) CG cells, raising the question as to which molecule acts as the blocking particle in CG cells. However, because we did not specifically look at the expression of $\beta 4$ subunits, we cannot rule out a contribution of $\beta 4$ subunits in CG cell KO mice. Whatever the identity of the blocking particle, our data show that Nav1.2 can undergo the resurgence process at least as well as Nav1.6 in CG cells.

While showing that loss of Nav1.6 does not significantly affect $I_{\mathrm{NaR}}$ in CG cells, our data revealed that the same condition results in a significant reduction of $I_{\mathrm{NaP}}$. Thus, Nav1.2 channels that remain in CG cells of Scn8a KO animals are not capable of passing steady-state current as well as Nav1.6 channels. This is consistent with previous data showing that $I_{\mathrm{NaP}}$ is markedly reduced in brain neurons from Nav1.6-null mice (Raman et al. 1997; Maurice et al. 2001; Enomoto et al. 2007; Royeck et al. 2008), and that Nav1.1 and Nav1.2 yield smaller persistent currents in heterologous expression systems (Smith \& Goldin, 1998; Rush et al. 2005). Thus, our data add to the previous results in suggesting that Nav1.6 subunits are more effective than other isoforms in generating persistent $\mathrm{Na}^{+}$currents.

Functional evidences suggest a difference in the propensity of different neuronal compartments to generate $I_{\mathrm{NaP}}$ (Osorio et al. 2005; Yue et al. 2005; Astman et al. 2006). Our previous experiments using focal application of TTX onto the soma of CG cells indicated that channels responsible for $I_{\mathrm{NaP}}$ are located on axonal processes but not in the cell body plasma membrane (Osorio et al. 2005). In addition, somatic and dendritic Nav channels in layer 5 neocortical neurons have been shown to play a minimal role in generating $I_{\mathrm{NaP}}$, which appears to be almost entirely carried by channels located in the proximal axon (Astman et al. 2006). These observations together with our findings that somato-dendritic compartments of CG cells are

representative responses of CG cells from a WT (P45, left) and an Snc8a CG KO (P41, right) mice to increasing current injections. $H$, cumulative plot showing the difference in the distribution of the interspike intervals in WT (black line) and Snc8a KO CG cells (grey line) measured following a +40 pA current step (Kolmogorov-Smirnov test: $P<0.001)$. I, average mean firing rate plotted against current intensity for WT CG cells (filled squares, $n=23$ ) and Snc8a KO CG cells (open squares, $n=17$ ). Straight lines are linear regression fits to data points, giving slope coefficients of 1.72 and $1.16 \mathrm{~Hz} \mathrm{pA}^{-1}$ for WT and Scn8a KO CG cells, respectively. 
not immunoreactive for $\mathrm{Nav}$ antibodies indicate that persistent Nav1.6 current is generated in the AISs where it is segregated.

\section{Nav1.6 channels regulate action potential waveform and spike timing}

Functional consequences of Nav1.6 elimination on CG cell excitability and firing pattern were analysed in mature cerebellar slices. Our data indicate that the absence of Nav1.6 in granule cells had no significant effects on the rheobase and threshold for AP generation. The observed reduction in $I_{\mathrm{NaP}}$ amplitude would, instead, be expected to increase the rheobase of AP discharge (Magistretti et al. 2006). Adaptive rearrangements in the balance between the conductances active in the subthreshold voltage range could explain this unexpected finding. On the other hand, AP duration was found to be significantly shortened in Scn8a KO granule cells, and AHP was significantly enhanced. This could be due to an acceleration of $I_{\mathrm{NaT}}$ kinetics. Indeed, in particular conditions (although not always: Do \& Bean, 2004; Enomoto et al. 2007) neuronal $\mathrm{Na}^{+}$currents produced in the absence of Nav1.6 channels inactivate more quickly than those due to Nav1.6 channels (Raman et al. 1997; Mercer et al. 2007). If inactivation of $\mathrm{Na}^{+}$channels is more complete in $S c n 8 a$ KO cells than in WT cells, the tail current flowing through non-inactivated channels during the AHP will be smaller. Consequently, the balance between inward currents and $\mathrm{K}^{+}$currents will move towards the latter, and a larger hyperpolarization will result.

In CA1 hippocampal pyramidal cells it has been shown that $I_{\mathrm{NaP}}$ contributes to amplify the post-spike AHP, and that its absence results in AHP decrease (Vervaeke et al. 2006). This is because $I_{\mathrm{NaP}}$ reduced the current injection required to elicit any given level of firing activity, whereas AHP peak occurred at potential levels more negative than those at which $I_{\mathrm{NaP}}$ is significantly activated. As a consequence, at the peak of the AHP the total depolarizing current was larger in the absence of $I_{\mathrm{NaP}}$, and AHP amplitude was reduced. Our observation that in Scn8a KO granule cells the AHP was enhanced even for equal levels of firing frequency indicates that, if the above mechanism is also active in CG cells, it is overcome, after abolition of Nav1.6 expression and the consequent $I_{\mathrm{NaP}}$ reduction, by additional mechanism(s) that tend to enhance the AHP.

Previous work suggested that $I_{\mathrm{NaP}}$ plays critical roles in other aspects of neuronal functions, including subthreshold oscillations and repetitive firing (Do \& Bean, 2003; Magistretti et al. 2006; Kang et al. 2007; Mercer et al. 2007). We found that Scn $8 a$ KO CG cells exhibited a mild - but not significant - impairment of frequency-current relationship compared with their WT counterparts. We showed that this subtle firing deficit in Scn8a KO CG cells was not the consequence of compensatory changes in expression of other Nav isoforms, since neither Nav1.1 nor Nav1.2 was upregulated during development nor took the place normally occupied by Nav1.6. It is not yet clear, however, whether other $\mathrm{K}^{+}$or $\mathrm{Ca}^{2+}$ currents exert compensatory effects (Swensen \& Bean, 2005) and influence the overall electrophysiological phenotype of CG cells in a manner to favour high frequency firing. Nevertheless, it may not be surprising that high frequency capability was so little affected in Scn8a KO CG cells, given that these cells showed normal $\mathrm{Na}^{+}$resurgent current, which is critical to fast spiking (Mercer et al. 2007).

One major difference between WT and Scn8a KO CG cells was a propensity for Scn8a KO CG cells to display increased interspike interval variability and firing irregularity. This observation may appear at odds with the observation of AHP enhancement, because spike afterhyperpolarization is a mechanism that improves temporal precision during AP trains (de Ruyter van Steveninck et al. 1997; Berry \& Meister, 1998; Vervaeke et al. 2006). Why then in the presence of a more profound AHP does the ISI interval variability not decrease, but, if anything, increase? This could be the result of a combination of factors. Per se, the enhanced AHP would tend to make firing precision higher: indeed, a more profound AHP promotes Nav channel repriming, and combined with resurgent gating it may allow membrane potential to rise back to spike threshold quickly, thus increasing spiking precision. On the other hand, the smaller $I_{\mathrm{NaP}}$ of $S c n 8 a \mathrm{KO}$ CG cells could make the slope of the interspike depolarizing ramp less steep, which would have the opposite effect on firing precision. Indeed, from Fig. $7 \mathrm{H}$ it can be seen that the slope of the cumulative plot at smaller ISI durations was higher (greater precision) in Scn8a KO CG cells than in WT cells, and somewhat lower (smaller precision) for longer ISI durations. This would mean that when the interspike phase lingers a little longer around the threshold, AP firing becomes less regular, perhaps because the depolarizing contribution of $I_{\mathrm{NaP}}$ is partially lacking.

In conclusion, our results demonstrate that in CG cells, Nav1.2 channels, clustered in the AISs in the absence of Nav1.6 channels, can generate normal levels of transient and resurgent $\mathrm{Na}^{+}$currents, and sustain a high-frequency firing that appears normal in many respects. However, Nav1.6 channels seem to be required for normal expression of persistent $\mathrm{Na}^{+}$current and to warrant a high degree of temporal precision in repetitive firing of CG cells.

\section{References}

Afshari FS, Ptak K, Khaliq ZM, Grieco TM, Slater NT, McCrimmon DR \& Raman IM (2004). Resurgent Na currents in four classes of neurons of the cerebellum. J Neurophysiol 92, 2831-2843. 
Aller MI, Jones A, Merlo D, Paterlini M, Meyer AH, Amtmann U, Brickley S, Jolin HE, McKenzie AN, Monyer H, Farrant M \& Wisden W (2003). Cerebellar granule cell Cre recombinase expression. Genesis 36, 97-103.

Aman TK \& Raman IM (2007). Subunit dependence of $\mathrm{Na}$ channel slow inactivation and open channel block in cerebellar neurons. Biophys J 92, 1938-1951.

Astman N, Gutnick MJ \& Fleidervish IA (2006). Persistent sodium current in layer 5 neocortical neurons is primarily generated in the proximal axon. J Neurosci 26, 3465-3473.

Berry MJ 2nd \& Meister M (1998). Refractoriness and neural precision. J Neurosci 18, 2200-2211.

Boiko T, Rasband MN, Levinson SR, Caldwell JH, Mandel G, Trimmer JS \& Matthews G (2001). Compact myelin dictates the differential targeting of two sodium channel isoforms in the same axon. Neuron 30, 91-104.

Boiko T, Van Wart A, Caldwell JH, Levinson SR, Trimmer JS \& Matthews G (2003). Functional specialization of the axon initial segment by isoform-specific sodium channel targeting. J Neurosci 23, 2306-2313.

Bouzidi M, Tricaud N, Giraud P, Kordeli E, Caillol G, Deleuze C, Couraud F \& Alcaraz G (2002). Interaction of the Nav1.2a subunit of the voltage-dependent sodium channel with nodal ankyrinG. In vitro mapping of the interacting domains and association in synaptosomes. J Biol Chem 277, 28996-29004.

Burgess DL, Kohrman DC, Galt J, Plummer NW, Jones JM, Spear B \& Meisler MH (1995). Mutation of a new sodium channel gene, Scn8a, in the mouse mutant 'motor endplate disease'. Nat Genet 10, 461-465.

Cathala L, Brickley S, Cull-Candy S \& Farrant M (2003). Maturation of EPSCs and intrinsic membrane properties enhances precision at a cerebellar synapse. J Neurosci 23, 6074-6085.

Castelli L, Biella G, Toselli M \& Magistretti J (2007a). Resurgent $\mathrm{Na}^{+}$current in pyramidal neurones of rat perirhinal cortex layer II: Axonal location of channels and contribution to depolarising drive during repetitive firing. J Physiol 582, 1179-1193.

Castelli L, Nigro MJ \& Magistretti J (2007b). Analysis of resurgent sodium-current expression in rat parahippocampal cortices and hippocampal formation. Brain Res 1163, 44-55.

Chadderton P, Margrie TW \& Hausser M (2004). Integration of quanta in cerebellar granule cells during sensory processing. Nature 428, 856-860.

Crill WE (1996). Persistent sodium current in mammalian central neurons. Annu Rev Physiol 58, 349-362.

Cummins TR, Dib-Hajj SD, Herzog RI \& Waxman SG (2005). Nav1.6 channels generate resurgent sodium currents in spinal sensory neurons. FEBS Lett 579, 2166-2170.

D’Angelo E, De Filippi G, Rossi P \& Taglietti V (1997). Synaptic activation of $\mathrm{Ca}^{2+}$ action potentials in immature rat cerebellar granule cells in situ. J Neurophysiol 78, 1631-1642.

D’Angelo E, Nieus T, Maffei A, Armano S, Rossi P, Taglietti V, Fontana A \& Naldi G (2001). Theta-frequency bursting and resonance in cerebellar granule cells: experimental evidence and modelling of a slow $\mathrm{K}^{+}$-dependent mechanism. J Neurosci 21, 759-770. de Ruyter van Steveninck RR, Lewen GD, Strong SP, Koberle R \& Bialek W (1997). Reproducibility and variability in neural spike trains. Science 275, 1805-1808.

Diwakar S, Magistretti J, Goldfarb M, Naldi G \& D'Angelo E (2009). Axonal $\mathrm{Na}^{+}$channels ensure fast spike activation and back-propagation in cerebellar granule cells. J Neurophysiol 101, 519-532.

Do MT \& Bean BP (2003). Subthreshold sodium currents and pacemaking of subthalamic neurons: modulation by slow inactivation. Neuron 39,109-120.

Do MT \& Bean BP (2004). Sodium currents in subthalamic nucleus neurons from Nav1.6-null mice. J Neurophysiol 92, 726-733.

Drews VL, Lieberman AP \& Meisler MH (2005). Multiple transcripts of sodium channel SCN8A (NaV1.6) with alternative $5^{\prime}$ - and $3^{\prime}$-untranslated regions and initial characterization of the SCN8A promoter. Genomics 85, 245-257.

Drummond GB (2009). Reporting ethical matters in The Journal of Physiology: standards and advice. J Physiol 587, 713-719.

Enomoto A, Han JM, Hsiao CF \& Chandler SH (2007). Sodium currents in mesencephalic trigeminal neurons from Nav1.6 null mice. J Neurophysiol 98, 710-719.

Enomoto A, Han JM, Hsiao CF, Wu N \& Chandler SH (2006). Participation of sodium currents in burst generation and control of membrane excitability in mesencephalic trigeminal neurons. J Neurosci 26, 3412-3422.

Fleidervish IA \& Gutnick MJ (1996). Kinetics of slow inactivation of persistent sodium current in layer $\mathrm{V}$ neurons of mouse neocortical slices. J Neurophysiol 76, 2125-2130.

Goldin AL (2001). Resurgence of sodium channel research. Annu Rev Physiol 63, 871-894.

Grieco TM, Malhotra JD, Chen C, Isom LL \& Raman IM (2005). Open-channel block by the cytoplasmic tail of sodium channel $\beta 4$ as a mechanism for resurgent sodium current. Neuron 45, 233-244.

Grieco TM \& Raman IM (2004). Production of resurgent current in Nav1.6-null Purkinje neurons by slowing sodium channel inactivation with $\beta$-pompilidotoxin. J Neurosci 24, 35-42.

Hamill, OP, Marty A, Neher E, Sakmann B \& Sigworth FJ (1981). Improved patch-clamp techniques for highresolution current recording from cells and cell-free membrane patches. Pflugers Arch 391, 85-100.

$\mathrm{Hu}$ W, Tian C, Li T, Yang M, Hou H \& Shu Y (2009). Distinct contributions of $\mathrm{Na}_{\mathrm{v}} 1.6$ and $\mathrm{Na}_{\mathrm{v}} 1.2$ in action potential initiation and backpropagation. Nat Neurosci 12, 996-1002.

Isope P \& Barbour B (2002). Properties of unitary granule cell->Purkinje cell synapses in adult rat cerebellar slices. J Neurosci 22, 9668-9678.

Isope P, Franconville R, Barbour B \& Ascher P (2004). Repetitive firing of rat cerebellar parallel fibres after a single stimulation. J Physiol 554, 829-839.

Jenkins SM \& Bennett V (2001). Ankyrin-G coordinates assembly of the spectrin-based membrane skeleton, voltage-gated sodium channels, and L1 CAMs at Purkinje neuron initial segments. J Cell Biol 155, 739-746. 
Jörntell H \& Ekerot CF (2006). Properties of somatosensory synaptic integration in cerebellar granule cells in vivo. J Neurosci 8, 11786-11797.

Kang Y, Saito M, Sato H, Toyoda H, Maeda Y, Hirai T \& Bae YC (2007). Involvement of persistent $\mathrm{Na}^{+}$current in spike initiation in primary sensoryneurons of the rat mesencephalic trigeminal nucleus. J Neurophysiol 97, 2385-2393.

Kaplan MR, Cho MH, Ullian EM, Isom LL, Levinson SR \& Barres BA (2001). Differential control of clustering of the sodium channels $\mathrm{Na}_{\mathrm{v}} 1.2$ and $\mathrm{Na}_{\mathrm{v}} 1.6$ at developing CNS nodes of Ranvier. Neuron 30, 105-119.

Khaliq ZM, Gouwens NW \& Raman IM (2003). The contribution of resurgent sodium current to high-frequency firing in Purkinje neurons: an experimental and modelling study. J Neurosci 23, 4899-4912.

Kohrman DC, Harris JB \& Meisler MH (1996). Mutation detection in the med and medJ alleles of the sodium channel Scn8a. Unusual splicing due to a minor class AT-AC intron. J Biol Chem 271, 17576-17581.

Laurie DJ, Wisden W \& Seeburg PH (1992). The distribution of thirteen $\mathrm{GABA}_{\mathrm{A}}$ receptor subunit mRNAs in the rat brain. III. Embryonic and postnatal development. J Neurosci 12, 4151-4172.

Levin SI, Khaliq ZM, Aman TK, Grieco TM, Kearney JA, Raman IM \& Meisler MH (2006). Impaired motor function in mice with cell-specific knockout of sodium channel Scn8a (Nav1.6) in cerebellar Purkinje neurons and granule cells. J Neurophysiol 96, 785-793.

Levin SI \& Meisler MH (2004). Floxed allele for conditional inactivation of the voltage-gated sodium channel Scn8a (NaV1.6). Genesis 39, 234-239.

Lorincz A \& Nusser Z (2008). Cell-type-dependent molecular composition of the axon initial segment. J Neurosci 31, 14329-14340.

Magistretti J \& Alonso A (1999). Biophysical properties and slow-voltage dependent inactivation of a sustained sodium current in entorhinal cortex layer-II principal neurons: A whole-cell and single-channel study. J Gen Physiol 114, 491-509.

Magistretti J, Castelli L, Forti L \& D’Angelo E (2006). Kinetic and functional analysis of transient, persistent and resurgent sodium currents in rat cerebellar granule cells in situ: an electrophysiological and modelling study. J Physiol 573, 83-106.

Maurice N, Tkatch T, Meisler M, Sprunger LK \& Surmeier DJ (2001). D1/D5 dopamine receptor activation differentially modulates rapidly inactivating and persistent sodium currents in prefrontal cortex pyramidal neurons. J Neurosci 21, 2268-2277.

Meisler MH \& Kearney JA (2005). Sodium channel mutations in epilepsy and other neurological disorders. J Clin Invest 115, 2010-2017.

Meisler MH, Plummer NW, Burgess DL, Buchner DA \& Sprunger LK (2004). Allelic mutations of the sodium channel SCN8A reveal multiple cellular and physiological functions. Genetica 122, 37-45.
Mercer JN, Chan CS, Tkatch T, Held J \& Surmeier DJ (2007). Nav1.6 sodium channels are critical to pacemaking and fast spiking in globus pallidus neurons. J Neurosci 27, 13552-13566.

Osorio N, Alcaraz G, Padilla F, Coste B, Delmas P \& Crest M (2005). Differential targeting and functional specialization of sodium channels in cultured cerebellar granule cells.

J Physiol 569, 801-816.

Raman IM \& Bean BP (1997). Resurgent sodium current and action potential formation in dissociated cerebellar Purkinje neurons. J Neurosci 17, 4517-4526.

Raman IM, Sprunger LK, Meisler MH \& Bean BP (1997). Altered subthreshold sodium currents and disrupted firing patterns in Purkinje neurons of Scn8a mutant mice. Neuron 19, 881-891.

Royeck M, Horstmann M-T, Remy S, Reitze M, Yaari Y \& Beck $\mathrm{H}$ (2008). Role of axonal Nav1.6 sodium channels in action potential initiation of CA1 Pyramidal neurons. J Neurophysiol 100, 2361-2380.

Rush AM, Dib-Hajj SD \& Waxman SG (2005). Electrophysiological properties of two axonal sodium channels, Nav1.2 and Nav1.6, expressed in mouse spinal sensory neurones. J Physiol 564, 803-815.

Smith RD \& Goldin AL (1998). Functional analysis of the rat I sodium channel in Xenopus oocytes. J Neurosci 18, 811-820.

Smith MR, Smith RD, Plummer NW, Meisler MH \& Goldin AL (1998). Functional analysis of the mouse Scn8a sodium channel. J Neurosci 18, 6093-6102.

Swensen A \& Bean BP (2003). Ionic mechanisms of burst firing in dissociated Purkinje neurons. J Neurosci 23, 9650-9663.

Swensen AM \& Bean BP (2005). Robustness of burst firing in dissociated purkinje neurons with acute or long-term reductions in sodium conductance. J Neurosci 25 , 3509-3520.

Trimmer JS \& Rhodes KJ (2004). Localization of voltage-gated ion channels in mammalian brain. Annu Rev Physiol 66, 477-519.

Truett GE, Heeger P, Mynatt RL, Truett AA, Walker JA \& Warman ML (2000). Preparation of PCR-quality mouse genomic DNA with hot sodium hydroxide and tris (HotSHOT). Biotechniques 29, 52-54.

Trudeau MM, Dalton JC, Day JW, Ranum LP \& Meisler MH (2006). Heterozygosity for a protein truncation mutation of sodium channel SCN8A in a patient with cerebellar atrophy, ataxia, and mental retardation. J Med Genet 43, 527-530.

Van Wart A \& Matthews G (2006). Impaired firing and cell-specific compensation in neurons lacking Nav1.6 sodium channels. J Neurosci 26, 7172-7180.

Vervaeke K, Hu H, Graham LJ \& Storm JF (2006). Contrasting effects of the persistent $\mathrm{Na}^{+}$current on neuronal excitability and spike timing. Neuron 49, 257-270.

Waxman SG \& Quick DC (1978). Functional architecture of the initial segment. In Physiology and Pathobiology of Axons, ed. Waxman SG, pp. 125-130. Raven Press, New York. 
Yu FH, Westenbroek RE, Silos-Santiago I, McCormick KA, Lawson D, Ge P, Ferriera H, Lilly J, DiStefano PS, Catterall WA, Scheuer T \& Curtis R (2003). Sodium channel $\beta 4$, a new disulfide-linked auxiliary subunit with similarity to $\beta 2$. J Neurosci 23, 7577-7585.

Yue C, Remy S, Su H, Beck H \& Yaari Y (2005). Proximal persistent $\mathrm{Na}^{+}$channels drive spike afterdepolarizations and associated bursting in adult CA1 pyramidal cells. J Neurosci 25, 9704-9720.

\section{Author contributions}

N.O., L.C., J.M. and P.D. contributed to the conception, design, analysis and interpretation of the data presented in this paper. The immunohistochemical experiments were designed, carried out and analysed by N.O. The electrophysiological experiments were designed, carried out and analysed by L.C. and J.M. The manuscript was written by N.O., L.C., J.M. and P.D. and revised with the critical appraisal of L.C., M.H.M., M.C. and J.M. All authors approved the final version for publication.

\section{Acknowledgements}

We thank Dr G. Alcaraz for the rabbit polyclonal anti-ankyrin G antibody. We thank A. Fernandez and S. Roffe-Vidal and acknowledge the late J. C. Reynaud for excellent technical assistance and M. P. Blanchard for expert assistance with the confocal imaging. The monoclonal antibody anti-Nav1.6 K87A/10 was developed by and obtained from the UC Davis/NINDS/NIMH NeuroMab Facility, supported by NIH grant (U24NS050606) and maintained by the Department of Pharmacology, School of Medicine, University of California, Davis. This work was supported by the Centre National pour la Recherche Scientifique and by grants from the Agence Nationale de la Recherche (ANR-05-NEURO, ANR-05-PCOD, ANR-08-MNP, ANR-08-GENOPAT, ANR-09-MNP), Fondation Schlumberger, ARCInca-2006, UPSA, IRME, the Fondation pour la Recherche Médicale (équipe FRM 2007) (to P.D.), and the United States Public Health Service (NS34509 to M.H.M.). N.O. was the recipient of the grant from the Fondation pour la Recherche Médicale. 